\title{
Basin-scale variability of phytoplankton biomass, production and growth in the Atlantic Ocean
}

\author{
Emilio Marañón ${ }^{\mathrm{a}, *}$, Patrick M. Holligan ${ }^{\mathrm{b}}$, Manuel Varela ${ }^{\mathrm{c}}$, \\ Beatriz Mouriño ${ }^{\mathrm{a}}$, Anthony J. Bale ${ }^{\mathrm{d}}$
}

\author{
${ }^{a}$ Departamento de Ecología y Biología Animal, Universidad de Vigo, E-36200 Vigo, Spain \\ ${ }^{\mathrm{b}}$ School of Ocean and Earth Science, University of Southampton, Southampton Oceanography Centre, \\ Southampton SO14 3ZH, UK
}

'Instituto Español de Oceanografía, Centro Oceanográfico de A Coruña, Apdo 130, E-15080 A Coruña, Spain ${ }^{\mathrm{d}}$ Plymouth Marine Laboratory, Prospect Place, West Hoe, Plymouth PL1 3DH, UK

Received 14 November 1997; received in revised form 23 June 1999; accepted 3 August 1999

\begin{abstract}
The latitudinal distributions of phytoplankton biomass, composition and production in the Atlantic Ocean were determined along a $10,000-\mathrm{km}$ transect from $50^{\circ} \mathrm{N}$ to $50^{\circ} \mathrm{S}$ in October 1995, May 1996 and October 1996. Highest levels of euphotic layer-integrated chlorophyll $a(\mathrm{Chl} a)$ concentration $\left(75-125 \mathrm{mg} \mathrm{Chl} \mathrm{m}^{-2}\right.$ ) were found in North Atlantic temperate waters and in the upwelling region off NW Africa, whereas typical Chl $a$ concentrations in oligotrophic waters ranged from 20 to $40 \mathrm{mg} \mathrm{Chl} \mathrm{m}{ }^{-2}$. The estimated concentration of surface phytoplankton carbon $(\mathrm{C})$ biomass was $5-15 \mathrm{mg} \mathrm{C} \mathrm{m}^{-2}$ in the oligotrophic regions and increased over $40 \mathrm{mg} \mathrm{C} \mathrm{m}^{-2}$ in richer areas. The deep chlorophyll maximum did not seem to constitute a biomass or productivity maximum, but resulted mainly from an increase in the Chl $a$ to $\mathrm{C}$ ratio and represented a relatively small contribution to total integrated productivity. Primary production rates varied from $50 \mathrm{mg} \mathrm{C} \mathrm{m}^{-2} \mathrm{~d}^{-1}$ at the central gyres to $500-1000 \mathrm{mg} \mathrm{C} \mathrm{m}^{-2} \mathrm{~d}^{-1}$ in upwelling and higher latitude regions, where faster growth rates $(\mu)$ of phytoplankton $\left(>0.5 \mathrm{~d}^{-1}\right)$ were also measured. In oligotrophic waters, microalgal growth was consistently slow [surface $\mu$ averaged $0.21 \pm 0.02 \mathrm{~d}^{-1}$ (mean $\pm \mathrm{SE}$ )], representing $<20 \%$ of maximum expected growth. These results argue against the view that the subtropical gyres are characterized by high phytoplankton turnover rates. The latitudinal variations in $\mu$ were inversely correlated to the changes in the depth of the nitracline and positively correlated to those of the integrated nitrate concentration, supporting the case for the role of nutrients in controlling the large-scale distribution of phytoplankton growth rates. We observed a large degree of temporal
\end{abstract}

\footnotetext{
* Corresponding author. Tel.: + 34-986-812629; Fax: + 34-986-812556.

E-mail address: em@uvigo.es (E. Marañón)
} 
variability in the phytoplankton dynamics in the oligotrophic regions: productivity and growth rates varied in excess of 8 -fold, whereas microalgal biomass remained relatively constant. The observed spatial and temporal variability in the biomass specific rate of photosynthesis is at least three times larger than currently assumed in most satellite-based models of global productivity. (C) 2000 Elsevier Science Ltd. All rights reserved.

Keywords: Phytoplankton; Biomass; Primary production; Oligotrophic gyres; Atlantic Ocean; Large-scale variability

\section{Introduction}

In the oligotrophic regions of the ocean, the supply of inorganic nutrients to the euphotic layer may limit the concentration of microalgal biomass, the rate of phytoplankton growth, or both. Microalgal standing stocks in the central gyres are generally considered to be limited by nutrient supply. However, a precise solution to the question of whether phytoplankton growth rate is nutrient limited or not in the main subtropical gyres of the ocean remains elusive after several decades of debate (Eppley et al., 1973; Goldman et al., 1979; Platt and Harrison, 1985; Laws et al., 1987; Falkowski et al., 1992; Banse, 1995).

High growth rates can be sustained in nutrient-depleted waters if a tight coupling exists between regeneration of nutrients and their utilization by microalgae (McCarthy and Goldman, 1979). However, the measured zooplankton grazing rates and abundances are consistent with slow rather than fast phytoplankton growth (Jackson, 1980). The observation that the composition of the particulate organic matter (POM) in the open ocean roughly follows the Redfield ratios has been proposed as evidence for the lack of nutrient limitation of phytoplankton growth (Goldman et al., 1979), although the interpretation of POM compositional data in nutrient-depleted areas is greatly confounded by the large contribution of detritus and bacterial biomass (Fuhrman et al., 1989; Malone et al., 1993). Following Goldman's view, the oligotrophic regions could be regarded as highly balanced, quasi steady-state systems where phytoplankton are growing at near maximal rates $\left(>1 \mathrm{~d}^{-1}\right)$. In this scenario, temporal variability of productivity is small, and zooplankton are the main controlling factor through grazing and regeneration of nutrients (Banse, 1995). If, on the other hand, nutrient depletion causes low phytoplankton growth rates $\left(<0.3 \mathrm{~d}^{-1}\right)$, events of nutrient enrichment (e.g., Glover et al., 1988) will account for a major fraction of the annual primary production (Platt and Harrison, 1985). Accordingly, higher temporal variability in productivity will be expected and coupling between biomass production and consumption would not always be tight, thus affecting the export rate of the system (Karl et al., 1996). An additional implication is that nutrient-dependent physiological parameters should be incorporated into global models of production (Falkowski et al., 1992).

The range of estimates of phytoplankton growth in nutrient poor waters of the open oceans spans more than an order of magnitude from $\sim 0.1$ to $>1.5 \mathrm{~d}^{-1}$ (see review in Eppley, 1981). Early reports of low productivity in the subtropical gyres 
(Steeman-Nielsen and Jensen, 1957; Thomas, 1970; Eppley et al., 1973) have been considered to be in error due to methodological deficiencies (Fitzwater et al., 1982). Nevertheless, work carried out in oligotrophic waters using trace metal-clean techniques still shows a large range in the rates of phytoplankton production and growth (Malone et al., 1993; Letelier et al., 1996) implying that the 'old' measurements may not necessarily be underestimations. At the heart of this controversy lies a lack of knowledge about the temporal and spatial variability in the biology of the open ocean (Platt et al., 1989). As pointed out by Eppley (1981), horizontal and temporal variations need to be defined before any generalization about phytoplankton growth rates can be drawn. However, time series research programmes have no spatial resolution (Lohrenz et al., 1992; Karl and Lukas, 1996), and conversely the studies dealing with large spatial scales usually do not include a temporal component (Geider et al., 1993; Olaizola et al., 1996). Another dimension of the problem is that low-nutrient, open ocean regions have recently been estimated to contribute $80 \%$ of the global ocean production and $70 \%$ of the total export production (Karl et al., 1996). Consequently, any uncertainties in the productivity estimates in these areas will have significant effects on the predictions of global biogeochemical models.

The Atlantic Meridional Transect (AMT) programme offers a unique opportunity to conduct a basin-scale, quasi synoptic study of phytoplankton dynamics including a component of seasonal and interannual variation. Since September 1995, two meridional transects between Great Britain and the Falkland Islands have been carried out each year during the boreal spring and autumn. In this paper we report on the results from the first three cruises, which took place during September-October 1995 (AMT-1), April-May 1996 (AMT-2) and September-October 1996 (AMT-3). By describing the basin-scale, latitudinal patterns of phytoplankton biomass, composition and production in the Atlantic Ocean from $50^{\circ} \mathrm{N}$ to $50^{\circ} \mathrm{S}$, we aim to test the following hypotheses: (i) Phytoplankton are growing at high rates $\left(>1 \mathrm{~d}^{-1}\right)$ in the oligotrophic regions, (ii) Changes in productivity are due to variations in biomass, not photosynthetic efficiency, and (iii) Phytoplankton production and growth in the central gyres do not vary widely over time.

\section{Methods}

Three cruises were carried out on board RRS James Clark Ross on passage between Great Britain and the Falkland Islands during 21 September-24 October 1995 (AMT-1), 22 April-22 May 1996 (AMT-2) and 16 September-25 October 1996 (AMT-3) (see Fig. 1 for cruise tracks). During each cruise, a total of 25 productivity stations were sampled at intervals of approximately 270 nautical miles between $50^{\circ} \mathrm{N}$ and $50^{\circ} \mathrm{S}$. Sampling was conducted between 1100 and 1200 local time. At each station, seawater samples for the determination of chemical and biological variables were collected from 5-10 depths in the upper $200 \mathrm{~m}$ of the water column with a set of 12 metal-clean, lever action Teflon ${ }^{\circledR}$ Niskin bottles provided with silicone O-rings and seals. 


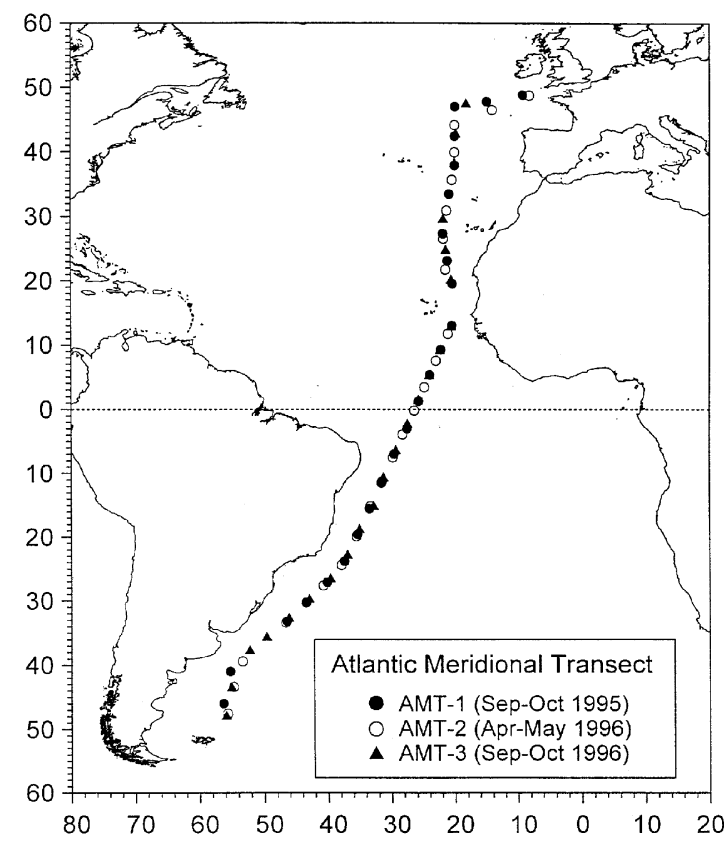

Fig. 1. Cruise tracks for the Atlantic Meridional Transect (AMT). Symbols indicate the position of the productivity stations.

\subsection{Irradiance, hydrography and nutrients}

The vertical distribution of photosynthetically active irradiance (PAR, 400-700 nm) was calculated by integrating the measurements of downwelling irradiance made with a SeaOPS Satlantic sensor at seven SeaWiFS wavelength bands. Incident PAR was continuously measured throughout the cruises by a Delta-T Instruments PAR sensor. The vertical distributions of temperature and salinity were measured with a Neil Brown Mark IIIB CTD. Inorganic nutrients were measured colourimetrically on fresh samples using a Technicon AAII Autoanalyser and standard techniques.

\subsection{Microplankton stock measurements}

Vertical profiles of in situ chlorophyll fluorescence were used to determine the sampling depths. Chlorophyll $a$ concentration was measured fluorometrically on $250-\mathrm{ml}$ samples filtered through $0.2 \mu \mathrm{m}$ polycarbonate filters and extracted in $90 \%$ acetone overnight. Calibration of the fluorometer was conducted before and after each cruise using pure chlorophyll $a$ (Sigma) as a standard. Duplicate 100-ml samples for the identification and counting of microplankton at selected depths were preserved in Lugol's iodine and $0.5 \%$ buffered formalin. Samples were allowed to settle in sedimentation chambers for $2-3 \mathrm{~d}$ and subsequently examined at 187 and 750 magnifications under an inverted microscope. Cell numbers were converted into 
carbon (C) biomass as described by Holligan et al. (1984). For picoplankton $(<2 \mu \mathrm{m})$, we calculated carbon biomass estimates by applying the conversion factors obtained by Zubkov et al. (1998) during AMT-3 using size-fractionation and flow cytometry techniques. Using the AMT-3 database, we compared total phytoplankton-C estimates based on the microscopic cell counts with $\mathrm{C}$ estimates in which the picoplanktonic biomass had been calculated from flow cytometry data. A highly significant linear relationship $\left(r^{2}=0.81, p<0.0001, n=59\right)$ existed between both types of estimates, and the differences in the total phytoplankton biomasses obtained from both approaches were not significant (paired differences $t$-test, $p>0.16, n=59$ ). Phytoplankton C estimates and derived parameters for AMT-3 were therefore calculated using the picoplankton abundances obtained from flow cytometry data.

\subsection{Productivity experiments}

The rates of inorganic carbon fixation were determined at 5-7 depths on each station by means of simulated in situ incubations with the radioisotope ${ }^{14} \mathrm{C}$. Incubation bottles were cleaned by soaking them in $1 \mathrm{~N} \mathrm{HCl}$ overnight and then rinsing them three times with deionized water. Seawater samples taken from the Niskin bottles were dispensed (through silicone rubber tubes) under dim light into 70-ml polycarbonate bottles, inoculated with $370-555 \mathrm{kBq}(10-15 \mu \mathrm{Ci}) \mathrm{NaH}^{14} \mathrm{CO}_{3}$ and incubated for 6-7 h. Incubations started within $30 \mathrm{~min}$ of sampling and were terminated at sunset. We did not find any significant differences between the average irradiance experienced by the phytoplankton populations during the experiments and the average irradiance measured throughout the day. Three light bottles and one dark bottle were incubated for each depth. Samples were placed inside acrylic neutral density tubes cooled with pumped surface seawater. Light profiles were simulated, according to the vertical PAR distribution measured prior to the incubation, with a set of neutral density and blue plastic filters. At the end of the incubations, samples were filtered through $0.2 \mu \mathrm{m}$ polycarbonate filters under low vacuum $(<100 \mathrm{~mm} \mathrm{Hg})$. Filters were exposed to concentrated $\mathrm{HCl}$ fumes overnight and then transferred to scintillation vials to which $4 \mathrm{ml}$ of scintillation cocktail were added. Radioactivity on each sample was determined on a Beckman LS6000 SC scintillation counter. Quenching was corrected with the channel ratio method. The standard error of the productivity estimates typically represented less than $10 \%$ of the mean value. Dark bottle values were subtracted from the counts obtained in the light samples (Banse, 1993). No significant differences were found between the radioactivity measured in the dark samples and that measured in the light samples at the bottom of the productivity profile.

\section{Results}

\subsection{Latitudinal distributions of temperature and nitrate}

The vertical distribution of temperature from $50^{\circ} \mathrm{N}$ to $50^{\circ} \mathrm{S}$ illustrates the range of oceanographic regimes that are sampled during the AMT cruises and the temporal 


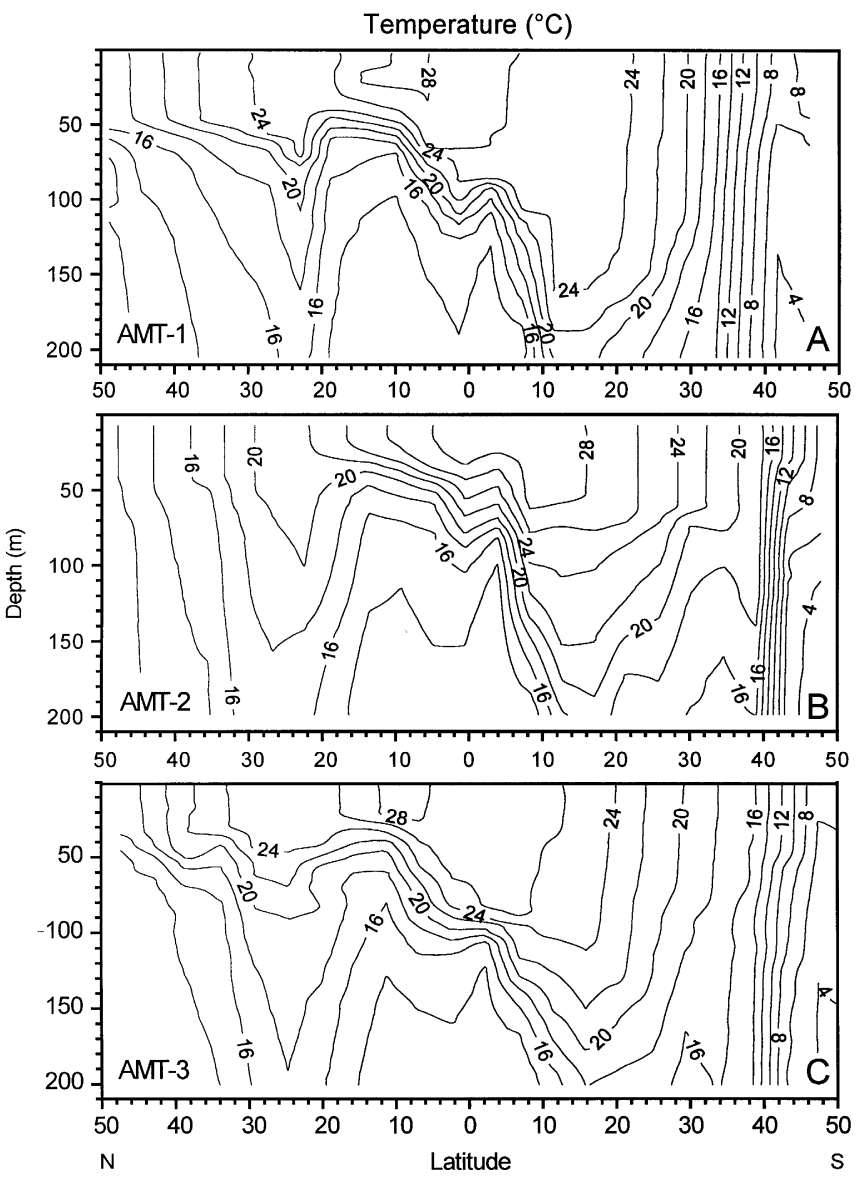

Fig. 2. Latitudinal distribution of temperature $\left({ }^{\circ} \mathrm{C}\right)$ during (A) AMT-1, (B) AMT-2 and (C) AMT-3. The contouring interval is $2^{\circ} \mathrm{C}$.

changes in the structure of the water column (Fig. 2). The main patterns of temperature distribution during September-October 1995 (AMT-1) and September-October 1996 (AMT-3) were similar (Fig. 2A and C). In the Northern hemisphere, upper mixed layer temperature increased from ca. $17^{\circ} \mathrm{C}$ at $50^{\circ} \mathrm{N}$ to ca. $23^{\circ} \mathrm{C}$ at $35^{\circ} \mathrm{N}$. The deepening of the $18^{\circ} \mathrm{C}$ isotherm marks the region where the transect crosses the eastern region of the North Atlantic gyre. A marked outcropping of the isotherms took place from $25^{\circ} \mathrm{N}$ to $20^{\circ} \mathrm{N}$, reflecting the cooling of subsurface waters as a result of the coastal upwelling off NW Africa. From approximately $20^{\circ} \mathrm{N}$ southwards, the position of the thermocline deepened progressively until $15^{\circ} \mathrm{S}$, and thereafter the temperature of the upper mixed layer decreased steadily. From $35^{\circ} \mathrm{S}$ to $45^{\circ} \mathrm{S}$, the transect crosses the South Subtropical Convergence (SSC) between the Brazil Current and the Falklands Current and surface temperature drops from $>15^{\circ} \mathrm{C}$ to $<8^{\circ} \mathrm{C}$. 


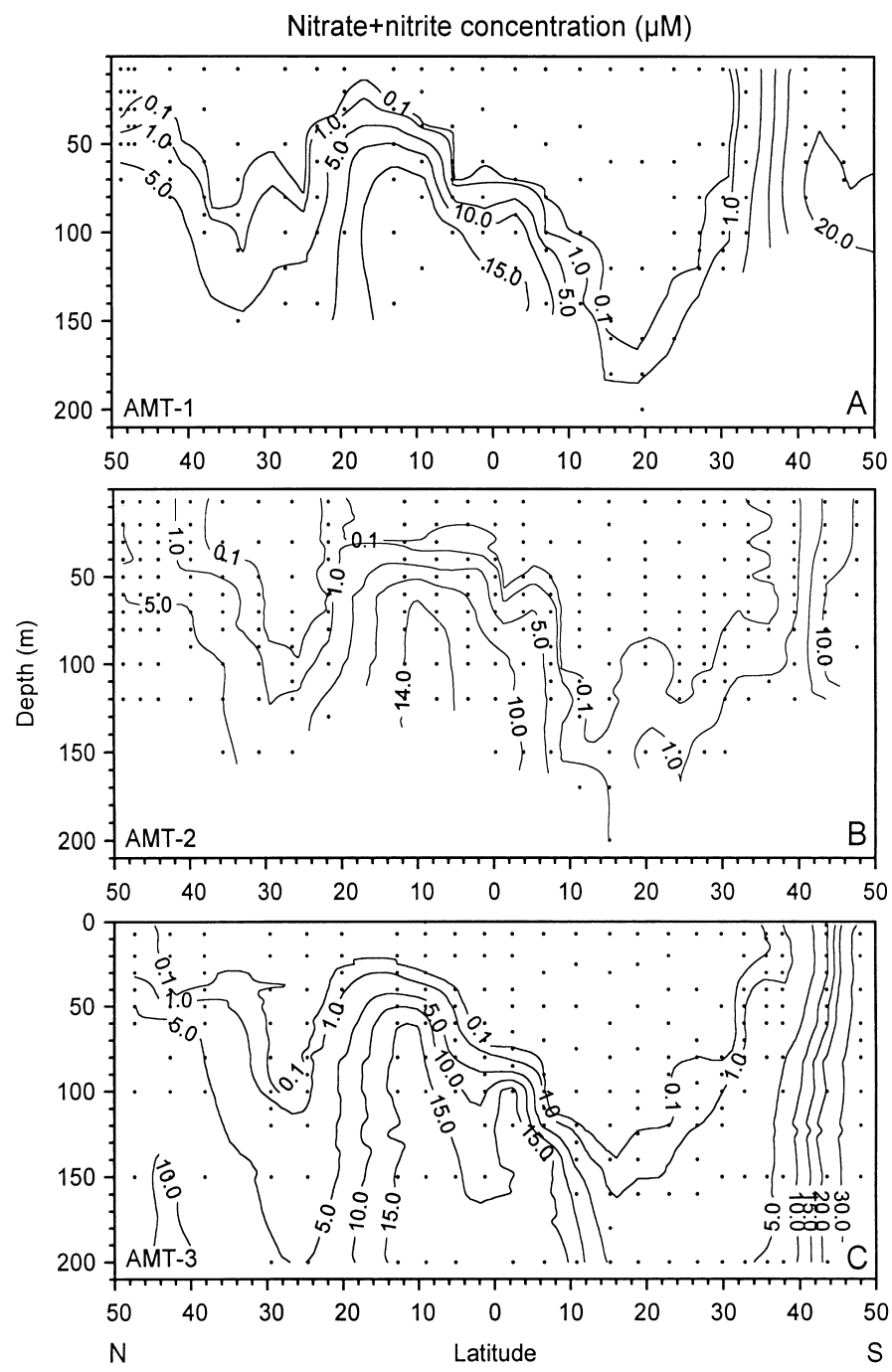

Fig. 3. Latitudinal distribution of the concentration of nitrate plus nitrite ( $\mu \mathrm{M})$ during (A) AMT-1, (B) AMT-2 and (C) AMT-3.

We found undetectable $(<0.05 \mu \mathrm{M})$ levels of nitrate plus nitrite in surface waters over long stretches of the transect (Fig. 3). The observed nutrient distribution in the oligotrophic regions agrees well with previous results obtained in both the North and the South Atlantic subtropical gyres (e.g. Frazel and Berberian, 1990; Hood, 1995). The latitudinal variations in the location of the nutricline followed those of the thermocline, and consequently the vertical extent of the nitrate-depleted waters was 
larger in the South Atlantic gyre than it was in the North Atlantic gyre. Increased nutrient concentrations in subsurface waters were measured between $20^{\circ}$ and $15^{\circ} \mathrm{N}$, indicating the proximity of the coastal upwelling area off NW Africa (e.g. Codispoti and Friederich, 1978). The increased subsurface nitrate concentrations persisted as far as $4-8^{\circ} \mathrm{S}$, reflecting the effects of the equatorial upwelling (Oudot and Morin, 1987). Highest nitrate concentrations $(>10 \mu \mathrm{M})$ in surface waters were always measured south of the SSC, where the vertical distribution of nutrients was relatively homogeneous.

The patterns of nitrate distribution in temperate latitudes changed markedly between cruises. North Atlantic surface waters were depleted of nitrate during the September-October (AMT-1 and AMT-3) cruises, whereas surface concentrations above $0.2 \mu \mathrm{M}$ and up to $2.5 \mu \mathrm{M}$ were measured from $35^{\circ} \mathrm{N}$ northwards during the April-May cruise (AMT-2). On the other hand, surface nitrate depletion in the South Atlantic Ocean extended further south $\left(35^{\circ} \mathrm{S}\right)$ during the AMT-2 cruise as compared to AMT-1 and AMT-3 cruises. Although the latter were conducted during the same time of the year (September-October), some differences in the nitrate distribution were found between these cruises: (i) nitrate depletion in the eastern North Atlantic waters extended further north and on average further down in the water column during AMT-1 (Fig. 3A), and (ii) measurable surface concentrations of nitrate ( $>0.05 \mu \mathrm{M}$ ) were found during AMT-3 throughout most of the southern central gyre (Fig. 3C).

\subsection{Chlorophyll a and phytoplankton biomass}

We measured low concentrations $\left(<0.4 \mathrm{mg} \mathrm{m}^{-3}\right)$ of chlorophyll $a(\mathrm{Chl} a)$ along most of the transect during the three cruises (Fig. 4). Lowest Chl $a$ levels were found in the equatorial region and in the tropical latitudes, where upper mixed layer concentrations were usually below $0.2 \mathrm{mg} \mathrm{m}^{-3}$ and occasionally (especially during September-October 1996) below $0.1 \mathrm{mg} \mathrm{m}^{-3}$. A distinct deep chlorophyll maximum (DCM) was present at the base of the euphotic layer at low latitudes, as previously reported in the Atlantic Ocean (e.g. Platt et al., 1983; Fasham et al., 1985; Frazel and Berberian, 1990). The DCM was characterized by Chl $a$ concentrations between 0.2 and $0.4 \mathrm{mg} \mathrm{m}^{-3}$ and was deeper in the southern central gyre, reflecting the deepening of the thermocline. The strong association between the location of the DCM and that of the thermocline is a well known feature of the tropical Atlantic Ocean (Herbland and Voituriez, 1979; Cox et al., 1982; Agustí and Duarte, 1999). The upwelling area off NW Africa displayed a marked increase in $\mathrm{Chl} a$, with concentrations above $1.5 \mathrm{mg} \mathrm{m}^{-3}$ recorded on AMT-1 and AMT-2 (Fig. 4).

The distribution of Chl $a$ in the temperate regions showed significant changes between cruises. During the boreal spring (AMT-2), increased Chl $a$ concentrations $\left(>1 \mathrm{mg} \mathrm{m}^{-3}\right.$ ) were found in North Atlantic waters (Fig. 4B), whereas the highest Chl $a$ levels $\left(>0.6 \mathrm{mg} \mathrm{m}^{-3}\right)$ we found in the southern end of the transect were measured during the austral spring (AMT-1 and AMT-3 cruises). The temporal changes in the abundance of phytoplankton pigment in the Atlantic Ocean are more evident when the latitudinal distributions of integrated $\mathrm{Chl} a$ during the three AMT cruises are 

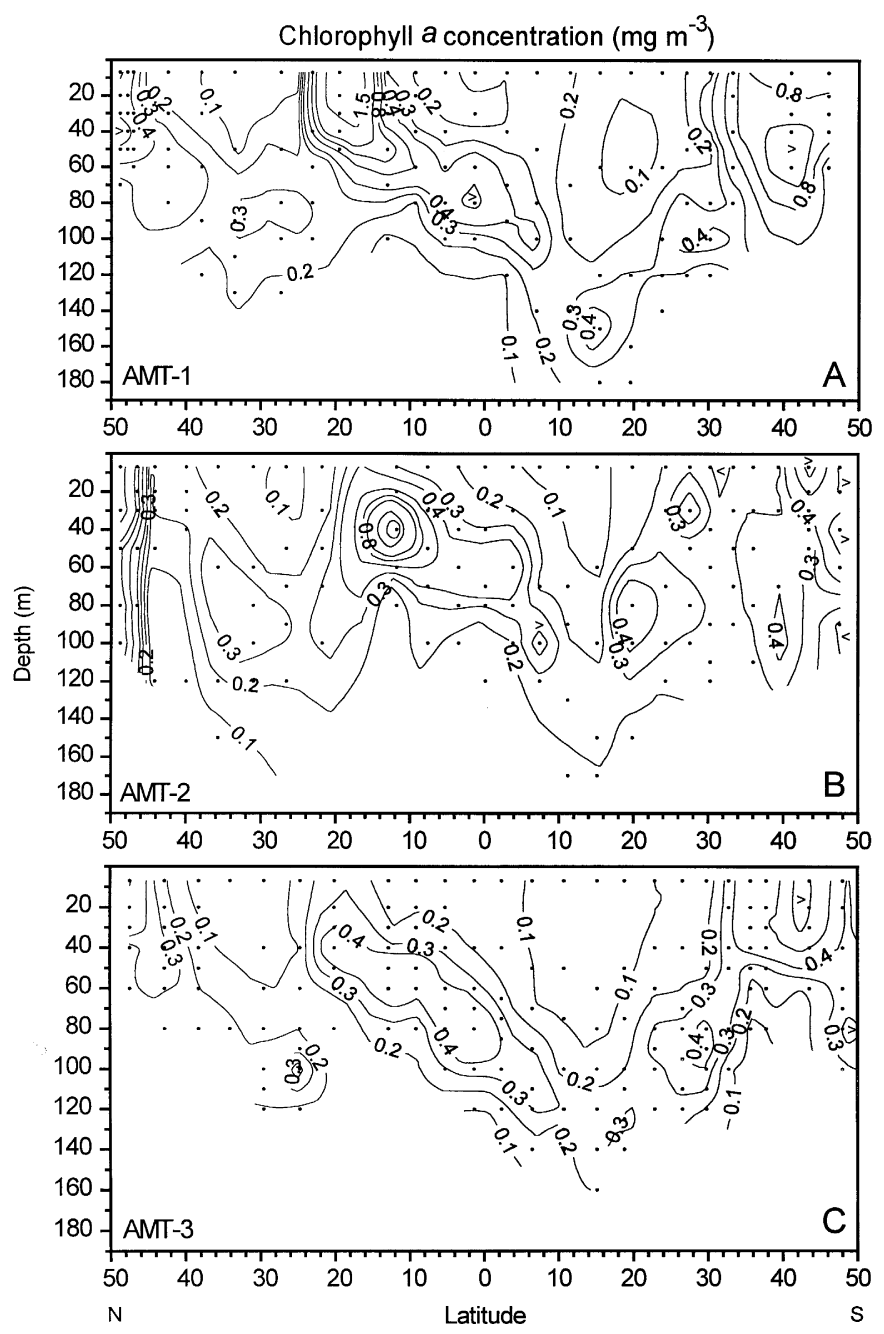

Fig. 4. Latitudinal distribution of chlorophyll $a$ concentration $\left(\mathrm{mg} \mathrm{m}^{-3}\right)$ during (A) AMT-1, (B) AMT-2 and (C) AMT-3. Contouring intervals are 0.1, 0.2, 0.3, 0.4, 0.6, 0.8, 1.0 and 1.5 and 2.0.

considered (Fig. 5A). During AMT-1, integrated Chl $a$ concentration in temperate South Atlantic waters was about $45 \mathrm{mg} \mathrm{m}^{-2}$, whereas values between 20 and $35 \mathrm{mg} \mathrm{m}^{-2}$ were measured in the central oligotrophic gyres. No increase in integrated Chl $a$ concentration was found in the southern end of the transect during the April-May cruise (AMT-2). Instead, we measured high Chl a concentrations (ca. $\left.125 \mathrm{mg} \mathrm{m}^{-2}\right)$ in North Atlantic waters $\left(48^{\circ} \mathrm{N}\right)$. In general, the integrated Chl $a$ concentration of the oligotrophic gyres remained within the range $15-30 \mathrm{mg} \mathrm{m}^{-2}$, and differences between cruises were usually smaller than a factor of two. These Chl $a$ 


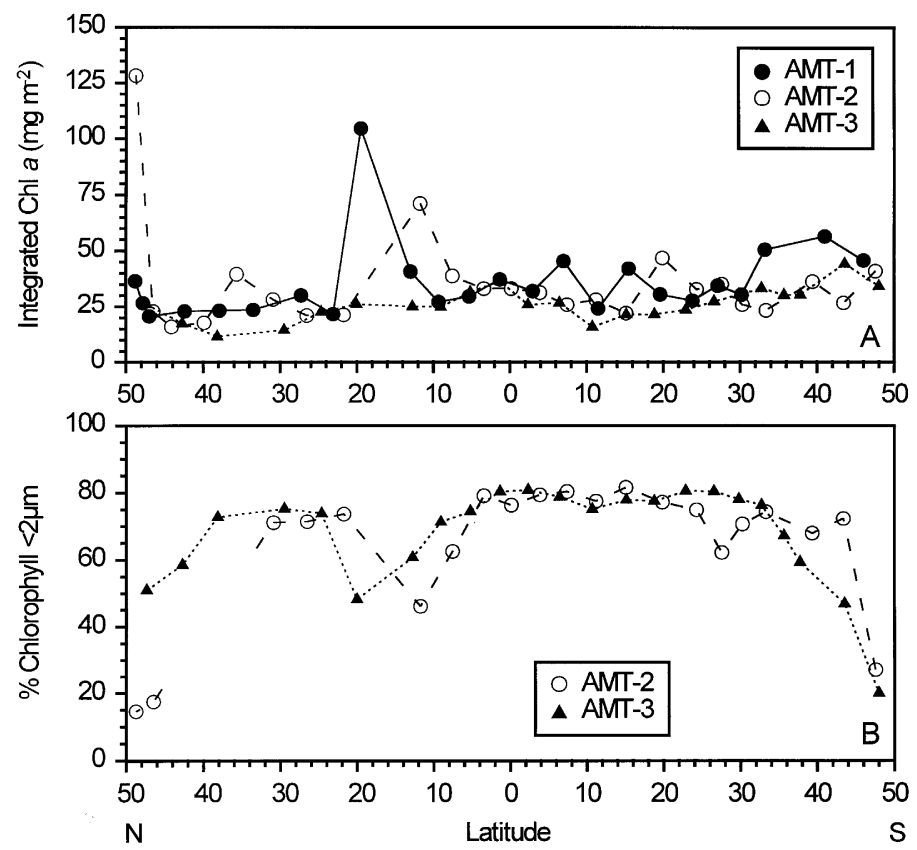

Fig. 5. Latitudinal distribution of (A) total integrated chlorophyll $a$ concentration $\left(\mathrm{mg} \mathrm{m}^{-2}\right)$ over the euphotic layer and (B) percentage of total integrated chlorophyll $a$ in the picoplankton $(<2 \mu \mathrm{m})$ size fraction. No size-fractionated Chl $a$ data are available for AMT-2 between $30^{\circ} \mathrm{N}$ and $45^{\circ} \mathrm{N}$.

levels fall well within the range of values reported during other large-scale studies in the North Atlantic subtropical gyre (Frazel and Berberian, 1990), the equatorial regions (Herbland et al., 1985) and the South Atlantic subtropical gyre (Hood, 1995). Picoplankton $(<2 \mu \mathrm{m})$ accounted for more than $60 \%$ of the total integrated $\mathrm{Chl}$ $a$ during most of the transect, excluding upwelling and temperate regions, where phytoplankton larger than $2 \mu \mathrm{m}$ were the dominant size fraction (Fig. 5B). This pattern was related to the distribution of the different groups of photosynthetic plankton (see below).

Typical surface phytoplankton C biomass in the oligotrophic regions was 5-10 mg $\mathrm{m}^{-3}$, whereas values between 20 and $60 \mathrm{mg} \mathrm{m}^{-3}$ were measured in temperate waters and in the upwelling region off NW Africa (Fig. 6A). High productivity regions were characterized by an increased abundance of diatoms (Fig. 6B), whereas in oligotrophic regions diatoms usually accounted for less than $2 \%$ of total photosyntetic biomass. The abundance of photosynthetic plankton in the subtropical gyres exhibited little temporal variability (Fig. 6A). In most cases, cyanobacteria (Synechococcus spp. and Prochlorococcus spp.) and small ( $\leqslant 5 \mu \mathrm{m}$ in diameter) flagellates were the dominant groups, accounting for $70-90 \%$ of the total photosynthetic $\mathrm{C}$ biomass (Fig. 6C and D). The latitudinal distribution of the relative abundance of cyanobacteria showed a distinct decrease in temperate waters (Fig. 6C), in close agreement with the observed 

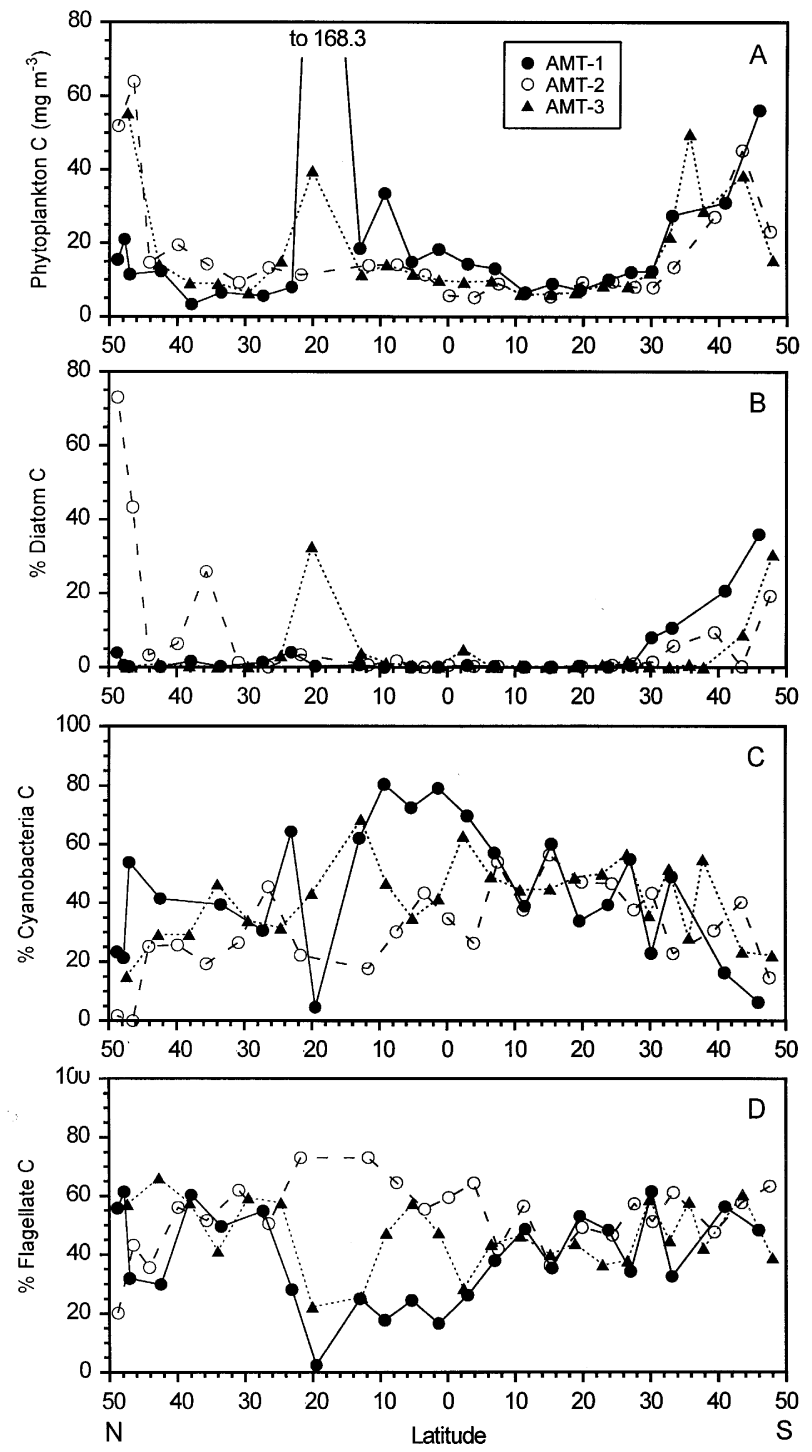

Fig. 6. Latitudinal distribution of surface $(7 \mathrm{~m})(\mathrm{A})$ total phytoplankton $\mathrm{C}$ biomass $\left(\mathrm{mg} \mathrm{m}^{-3}\right)$ and the relative contribution (\%) of (B) diatoms, (C) cyanobacteria and (D) flagellates to total phytoplankton biomass. Note differences in the $Y$-axis scale.

reduction in the contribution of picoplankton to total integrated Chl $a$ concentration (Fig. 5B). The fact that the phytoplankton size structure in the oligotrophic Atlantic regions is dominated by picoplankton has repeatedly been observed since the early work of Waterbury et al. (1979) and Herbland and Le Bouteiller (1981) and reflects a general feature of the open tropical ocean (Le Bouteiller et al., 1992). 
Other groups of phytoplankton like coccolithophores and dinoflagellates represented a minor contribution to the total microplankton biomass (data not shown). Coccolithophores typically accounted for $2-10 \%$ of the total photosynthetic biomass and were less abundant in the upwelling region between $5^{\circ} \mathrm{N}$ and $25^{\circ} \mathrm{N}$. Excluding a station at $20^{\circ} \mathrm{N}$ during AMT-1, where high abundances of Gymnodinium galeaeforme were measured, photosynthetic dinoflagellates usually contributed less than $4 \%$ to total photosynthetic $\mathrm{C}$ and were more abundant in northern temperate waters. Heterotrophic organisms (including heterotrophic dinoflagellates and protozoa but excluding bacteria) were also a small component of the microplankton, their typical biomass representing less than $5 \%$ of the total microplankton biomass (data not shown).

During AMT-3, we collected samples from three depths at each station in order to evaluate the vertical variability in the abundance of each phytoplankton group. Despite the vertical differences in $\mathrm{Chl} a$ concentration, surface samples were representative of the composition of the phytoplankton assemblages throughout the water column. Fig. 7 indicates that the latitudinal component is more relevant than the vertical one in controlling the variability of phytoplankton composition in terms of the main taxonomical groups. In addition, comparison of the vertical distribution of Chl $a$ concentration with that of total photosynthetic phytoplankton during AMT-3 (Figs. 4C and 7A, respectively) reveals that in general the deep chlorophyll maximum (DCM) was not a biomass maximum, but the result of a decrease with depth of the $\mathrm{C}$ to $\mathrm{Chl} a$ ratio. The same results were obtained during AMT-1 and AMT-2. Combining the observations carried out in oligotrophic areas (defined as the regions between $25^{\circ} \mathrm{N}-40^{\circ} \mathrm{N}$ and $10^{\circ} \mathrm{S}-30^{\circ} \mathrm{S}$ ) during the three cruises, we found that the average phytoplankton-C biomass at the DCM was $10.43 \pm 0.76 \mathrm{mg} \mathrm{m}^{-3}$, compared to $8.95 \pm 0.68 \mathrm{mg} \mathrm{m}^{-3}$ for surface samples. A paired samples $t$-test revealed that the differences in phytoplankton-C between surface and the DCM were not significant $(p>0.1, n=25)$. The average surface to DCM phytoplankton-C ratio was $0.92 \pm$ 0.08 , i.e. not significantly different from 1 . In contrast, the average $\mathrm{C}$ to $\mathrm{Chl} a$ ratio in the oligotrophic areas on the surface $(86.6 \pm 6.5, n=25)$ was twice as high as that measured at the DCM $(39.6 \pm 5.2, n=25)$. These differences in the $\mathrm{C}$ to $\mathrm{Chl} a$ ratio between surface and the DCM during the three cruises were highly significant (paired means $t$-test, $p<0.001, n=25$ ). During AMT-3, the DCM only represented a biomass maximum at two stations in the northern central gyre and two subequatorial stations north of the Equator (Fig. 7A). Between $0^{\circ} \mathrm{S}$ and $35^{\circ} \mathrm{S}$, where a marked DCM was always present, no significant differences were found in phytoplankton biomass between surface and depth.

During September-October 1996 (AMT-3), diatom abundance was important $(>10 \%)$ only in the upwelling area off NW Africa and south of the south subtropical convergence (Fig. 7B). Coccolithophores represented 5-10\% of the total phytoplankton $\mathrm{C}$ during most of the transect (data not shown). Cyanobacteria contributed $40-60 \%$ of total photosynthetic $\mathrm{C}$ throughout the water column in low latitudes, their relative abundance decreasing below $30 \%$ in temperate regions (Fig. 7C). The distribution of $\mathrm{N}_{2}$-fixing filamentous cyanobacteria (Trichodesmium spp.) during the SeptemberOctober 1996 cruise (AMT-3) is shown in Fig. 7D. Although these species were 

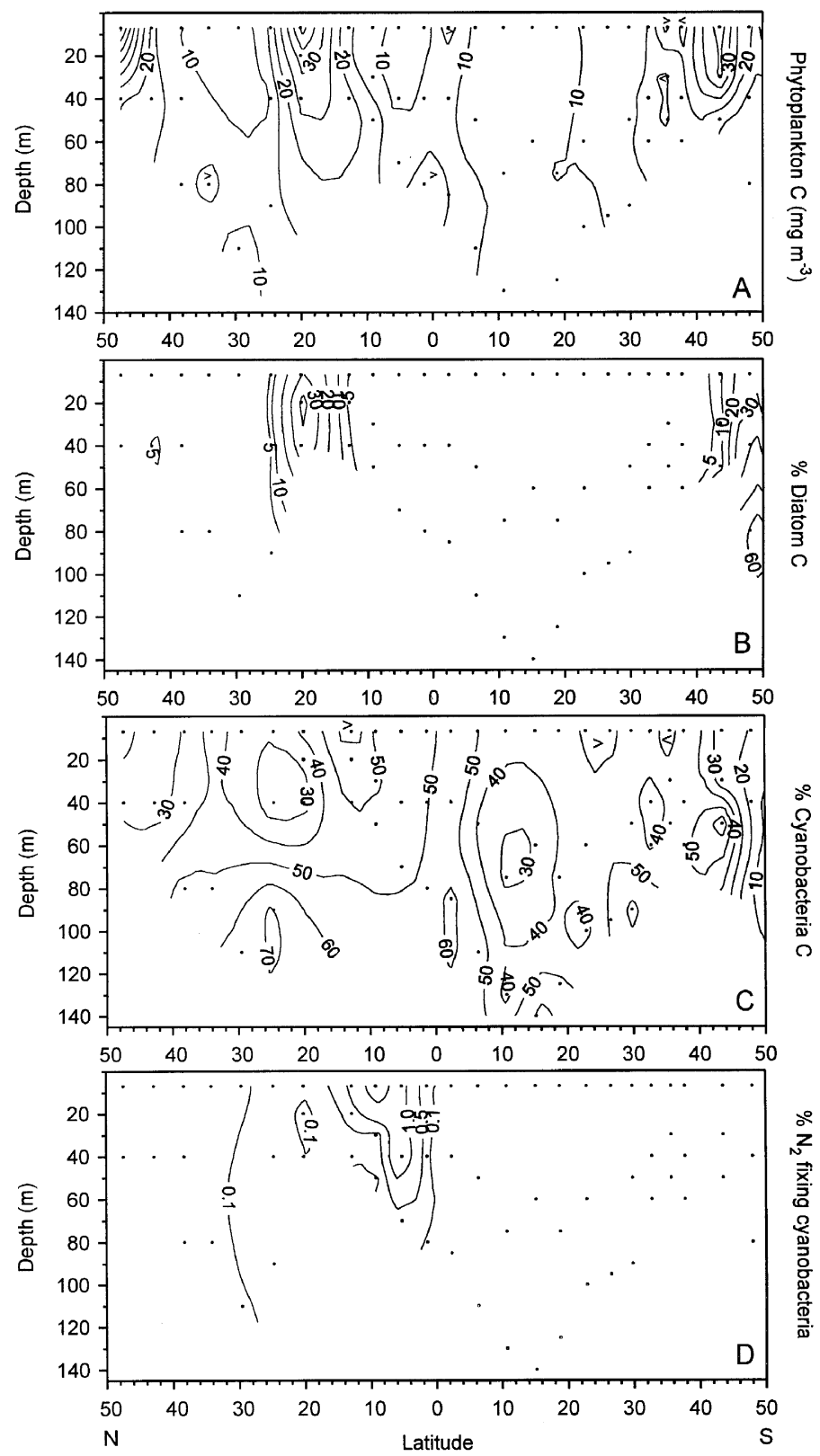

Fig. 7. Latitudinal distribution of (A) total phytoplankton $\mathrm{C}$ biomass $\left(\mathrm{mg} \mathrm{m}^{-3}\right)$ and the relative contribution (\%) of (B) diatoms, (C) cyanobacteria and (D) $\mathrm{N}_{2}$ fixing cyanobacteria during AMT-3. Contouring intervals are 10,15, 20, 25, 30, 40 and 45 in (A); 5, 10, 20, 30, 40, 50 and 60 in (B); 10, 20, 30, 40, 50 and 60 in (C); and $0.1,0.5,1$ and 2 in (D). 
undetectable during most of the cruise, they consistently concentrated in surface and subsurface waters between $20^{\circ} \mathrm{N}$ and the Equator, reaching maximum relative abundances of $2.5 \%$ of total photosynthetic biomass. The same latitudinal distribution was found during the September-October 1995 cruise (AMT-1) (data not shown). Even though we are aware that our sampling procedures were not well suited for an accurate quantification of the biomass of these species (see Capone et al., 1997), our results consistently show that the abundance of $\mathrm{N}_{2}$-fixing cyanobacteria increased dramatically in the region between the Equator and the upwelling area off NW Africa.

Considering all the samples collected during the 3 cruises, we observed that the concentration of photosynthetic phytoplankton carbon biomass (Phyto-C) was strongly correlated to $\mathrm{Chl} a$ concentration according to

$$
\begin{aligned}
& \text { Phyto }-\mathrm{C}=47.99( \pm 2.87) * \mathrm{Chl} a+0.64( \pm 1.47) \\
& \quad\left[r^{2}=0.63, n=163, p<0.001\right] .
\end{aligned}
$$

Fig. 8 shows the relationship between $\mathrm{Chl} a$ concentration and phytoplankton $\mathrm{C}$ concentration separately for surface $(7 \mathrm{~m})$ and deep samples. In order to avoid any possible distorting effects by rare, extreme values on the regression analysis, samples with high values of $\mathrm{Chl} a$ concentration $\left(>1 \mathrm{mg} \mathrm{m}^{-3}\right)$ and phytoplankton C concentration ( $>50 \mathrm{mg} \mathrm{C} \mathrm{m}^{-3}$ ) were excluded (less than $8 \%$ of all the samples). The slope of the regression line for surface samples was twice as large as that for deep samples, indicating higher $\mathrm{C}$ to $\mathrm{Chl} a$ ratios at the surface as previously mentioned. The correlation between $\mathrm{Chl} a$ concentration and phytoplankton $\mathrm{C}$ concentration at the surface (Fig. 8A) was stronger than at the DCM (Fig. 8B), probably reflecting the fact that the depth of the DCM was highly variable along the transect, therefore giving rise to changing $\mathrm{C}$ to $\mathrm{Chl} a$ ratios (see Discussion, Section 4).

In summary, the analysis of the distributions of Chl $a$ concentration and the abundance of the main phytoplankton groups indicates that (i) cyanobacteria and small flagellates account for $70-90 \%$ of total photosynthetic biomass throughout the oligotrophic Atlantic Ocean, (ii) the DCM is not generally a biomass maximum but the result of an increased $\mathrm{Chl} a$ to $\mathrm{C}$ ratio and (iii) the temporal variability in phytoplankton biomass and composition in the oligotrophic gyres is relatively small (less than a factor of 2).

\subsection{Phytoplankton production and growth}

The major patterns of distribution of primary production during the three cruises were similar (Fig. 9) and reflected the latitudinal variability of Chl $a$ concentration (Fig. 4). Higher rates of $\mathrm{C}$ fixation $\left(>0.5 \mathrm{mg} \mathrm{C} \mathrm{m}^{-3} \mathrm{~h}^{-1}\right)$ were measured in surface and subsurface waters of the temperate regions and the area between the Equator and the upwelling off NW Africa. By contrast, very low productivities $(<0.1-$ $0.2 \mathrm{mg} \mathrm{C} \mathrm{m}^{-3} \mathrm{~h}^{-1}$ ) were found in the central oligotrophic gyres and deeper waters throughout the transect. Excluding the temperate waters at both ends of the transect, picoplankton were responsible for most of the productivity, as the relative contribution of the $<2 \mu \mathrm{m}$ size fraction to total productivity ranged between $60 \%$ and $80 \%$ 

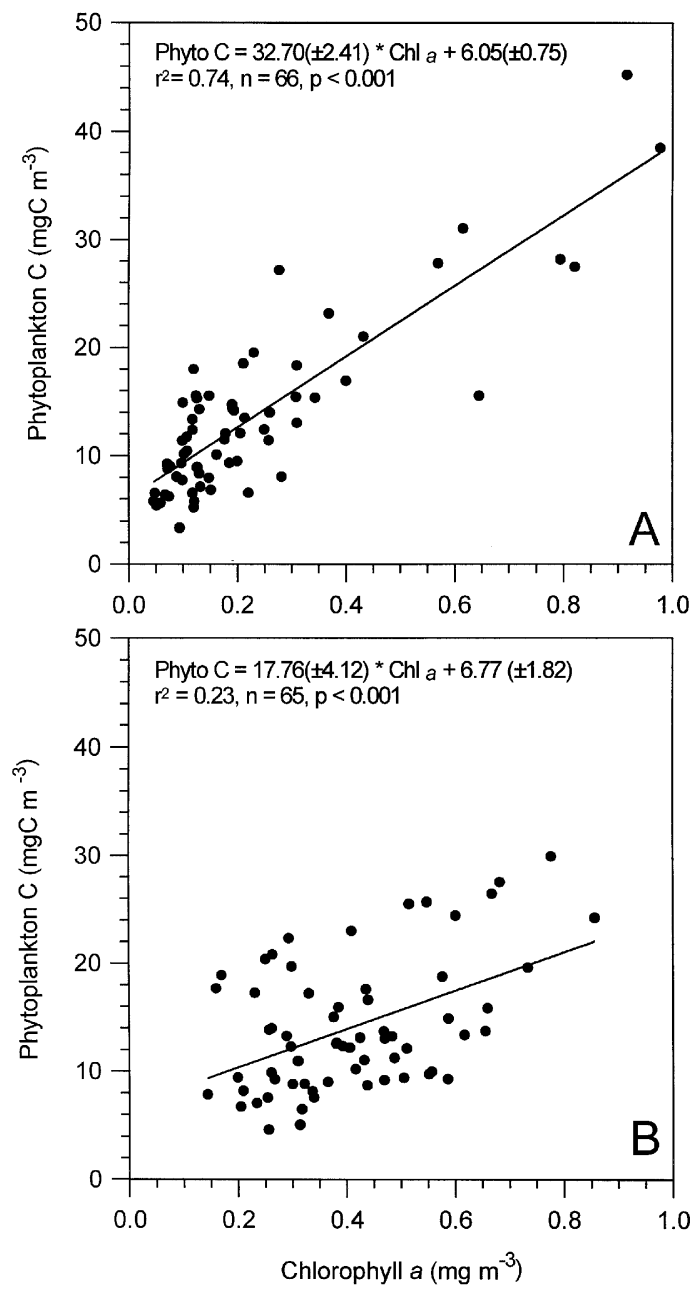

Fig. 8. Relationship between chlorophyll $a$ concentration and phytoplankton $\mathrm{C}$ as estimated from cell counts for (A) surface and (B) deep samples collected during the three cruises. Samples with Chl $a$ concentration above $1 \mathrm{mg} \mathrm{m}^{-3}$ and phytoplankton $\mathrm{C}$ above $50 \mathrm{mg} \mathrm{C} \mathrm{m}^{-3}$ ( $<8 \%$ of all samples) were excluded from the analysis (see text for details).

(data not shown). This dominance of picoplankton in terms of their contribution to total productivity agrees with previous observations in different nutrient-poor areas of the Atlantic Ocean (Platt et al., 1983; Iturriaga and Marra, 1988; Malone et al., 1993).

The main patterns of vertical distribution of primary production were the same during the three cruises (Fig. 9): C fixation in the more productive areas took place mainly in surface layers. In general, primary production did not increase at the deep 


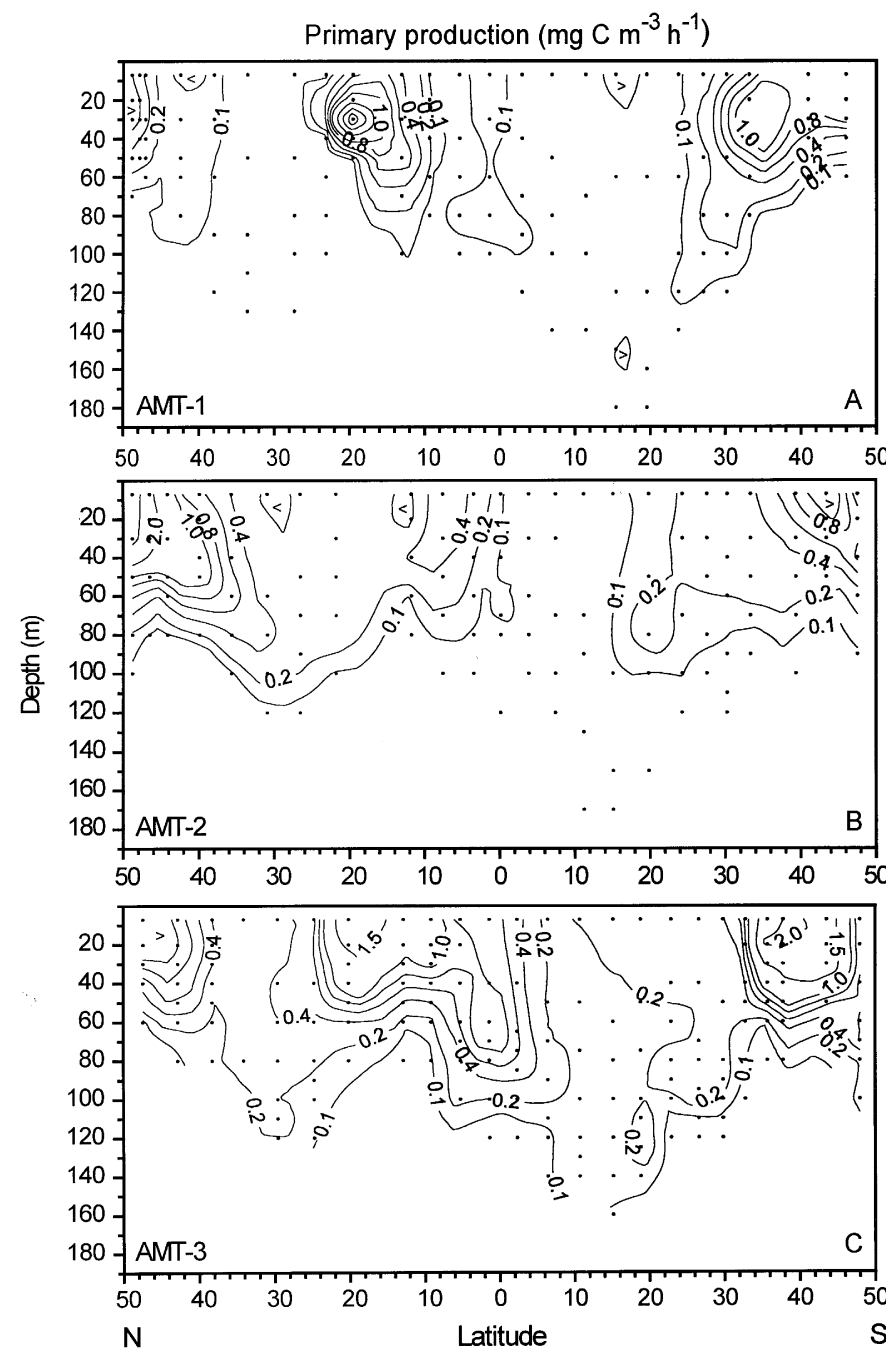

Fig. 9. Latitudinal distribution of primary production rate $\left(\mathrm{mg} \mathrm{C} \mathrm{m}^{-3} \mathrm{~h}^{-1}\right)$ during (A) AMT-1, (B) AMT-2 and (C) AMT-3. Contouring intervals are 0.1, 0.2, 0.4, 0.6, 0.8, 1.0, 1.5, 2.0 and 2.5 in (A); 0.1, 0.2, 0.4, 0.6, 0.8, $1.0,2.0$ and 4.0 in $(\mathrm{B})$; and $0.1,0.2,0.4,0.6,0.8,1.0,1.5$ and 2.0 in $(\mathrm{C})$.

chlorophyll maximum (DCM). Using the AMT-3 data set, we estimated the relative contribution of the DCM to total integrated Chl $a$ concentration and productivity by considering every sample where $[\mathrm{Chl} a] \geqslant 1.5[\mathrm{Chl} a]_{\text {surface }}$ belonged to the DCM. We found that, from $40^{\circ} \mathrm{N}$ to $40^{\circ} \mathrm{S}$, the DCM accounted for $61.5 \pm 3.5 \%$ of the total integrated $\mathrm{Chl} a$ whereas its contribution to the total integrated productivity was $37.0 \pm 2.0 \%$. 


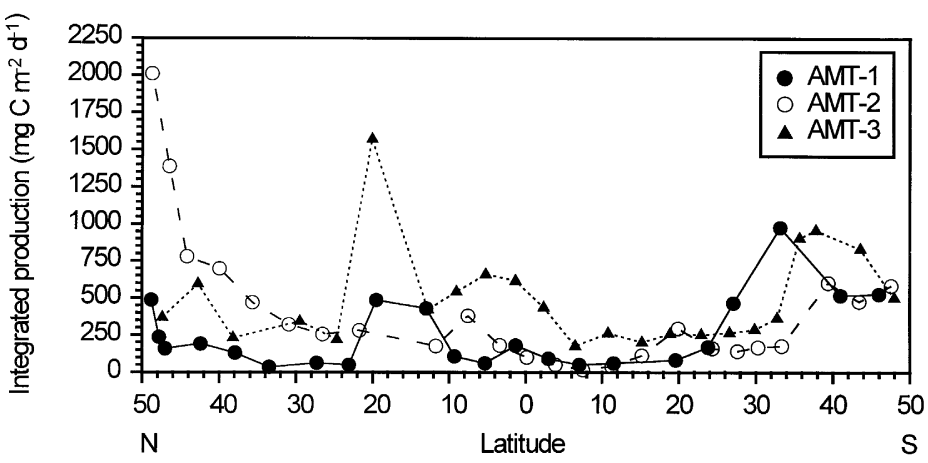

Fig. 10. Latitudinal distribution of daily rate of integrated primary production $\left(\mathrm{mg} \mathrm{C} \mathrm{m}^{-2} \mathrm{~d}^{-1}\right)$.

Fig. 10 allows an evaluation of the temporal variability of primary production in the Atlantic Ocean. In order to make our results more easily comparable with previous datasets, we converted the hourly production rates into daily rates by (i) taking into account the incident irradiance (PAR) integrated over both the incubation and the daylight time periods and (ii) assuming dark respiratory losses amount to $20 \%$ of the light ${ }^{14} \mathrm{C}$ incorporation. Phytoplankton respiration is a temperature and growth rate dependent process, and its magnitude is likely to undergo large variations along a basin-scale transect. The chosen value $(20 \%)$ is close to the lower limit of the range of respiratory losses measured in the ocean (see review by Geider, 1992).

The differences between cruises in the integrated productivity in the temperate regions were obvious (Fig. 10): increased productivity (>500 $\mathrm{m} \mathrm{C} \mathrm{m}^{-2} \mathrm{~d}^{-1}$ ) took place at the northern end of the transect during the boreal spring (AMT-2) and at the southern end of the transect during the austral spring (AMT-1 and AMT-3). Marked temporal variations in primary production were observed in the central gyres and the equatorial region. In the northern central gyre $\left(25^{\circ} \mathrm{N}-40^{\circ} \mathrm{N}\right)$, integrated production was very low (50-125 $\mathrm{mg} \mathrm{C} \mathrm{m}^{-2} \mathrm{~d}^{-1}$ ) during September-October 1995 (AMT-1), whereas typical values measured in the area during subsequent cruises were 250$500 \mathrm{mg} \mathrm{C} \mathrm{m}^{-2} \mathrm{~d}^{-1}$. Similarly, productivity in most of the equatorial region and the southern central gyre $\left(10^{\circ} \mathrm{N}-30^{\circ} \mathrm{S}\right)$ increased by a factor of 4-5 during September-October 1996 (AMT-3) in relation to the two previous cruises.

In addressing the causes of this variability in large areas of the oligotrophic ocean during the AMT programme, two facts should be taken into account. Firstly, the observed differences between cruises were not systematic: similar integrated productivity values were measured between $0^{\circ} \mathrm{S}$ and $30^{\circ} \mathrm{S}$ during AMT- 1 and AMT-2 and in the northern central gyre during AMT-2 and AMT-3. Even the variability in the primary production rates of the temperate regions was relatively small when the same seasons are compared. Secondly, the changes in productivity were not related to changes of Chl $a$ concentration or phytoplankton biomass and composition, which remained relatively constant in the oligotrophic areas during the three cruises (Figs. 5 and 6).

In order to assess the possible nutrient limitation of phytoplankton growth in the oligotrophic Atlantic Ocean, we estimated the daily specific growth rate $\left(\mu, \mathrm{d}^{-1}\right)$ of 
photosynthetic plankton according to the following equation:

$$
\mu=\ln \left[\left(C_{0}+\Delta C\right) / C_{0}\right]
$$

where $C_{0}$ is the photosynthetic carbon biomass as estimated from the microscope cell counts and $\Delta C$ is the daily rate of carbon fixation once the effects of incubation irradiance and respiration have been accounted for (see above). Although the actual values changed between cruises, the latitudinal variations of surface $\mu$ followed a similar pattern on each transect (Fig. 11): (i) higher growth rates were measured in temperate waters and the region including the upwelling area off NW Africa and subequatorial waters north of the Equator, (ii) $\mu$ increased with latitude during spring (southern hemisphere for AMT-1 and AMT-3 and northern hemisphere for AMT-2) and (iii) lower $\mu$ values were found in the central oligotrophic gyres. Average surface $\mu$ in the oligotrophic areas (defined as the regions between $25^{\circ} \mathrm{N}-40^{\circ} \mathrm{N}$ and $10^{\circ} \mathrm{S}-30^{\circ} \mathrm{S}$ ) was $0.21 \pm 0.02 \mathrm{~d}^{-1}$. There was a significant inverse relationship $(p<0.05, n=54)$ between the growth rate of surface phytoplankton and the depth of the nitracline as defined by the first depth where the concentration of nitrate was $\geqslant 1 \mu \mathrm{M}$ (Fig. 11).

During September-October 1995 (AMT-1), we estimated growth rates below $0.3 \mathrm{~d}^{-1}$ for the entire transect, higher values $\left(\geqslant 0.2 \mathrm{~d}^{-1}\right)$ being found in temperate and upwelling waters. Very low growth rates $\left(<0.1 \mathrm{~d}^{-1}\right)$ were measured in the central gyres during this cruise. In general, estimated growth rates increased during April-May 1996 (AMT-2) and, especially, September-October 1996 (AMT-3). Values of $\mu$ close to $0.4 \mathrm{~d}^{-1}$ were calculated for temperate waters of the North Atlantic during AMT-2 and the South Atlantic during AMT-3. In both cruises, an increase in $\mu$ was measured in the region between the Equator and $20^{\circ} \mathrm{N}$, although this increase was larger during AMT-3, when values up to $0.7 \mathrm{~d}^{-1}$ (equivalent to doubling times of $1 \mathrm{~d}$ ) were found in that region.

Fig. 12 shows the vertical distribution of the estimated phytoplankton growth rate in the Atlantic Ocean from $50^{\circ} \mathrm{N}$ to $50^{\circ} \mathrm{S}$ during September-October 1996 (AMT-3). Growth rates usually decreased with depth, although a slight increase in $\mu$ was measured at the base of the euphotic zone in the southern central gyre. The main features already described for the surface distribution are also evident in this plot. Highest growth rates $\left(>0.4 \mathrm{~d}^{-1}\right)$ were estimated for the upwelling and equatorial areas and for the temperate waters of the South Atlantic Ocean. The central oligotrophic gyres were characterized by low growth rates $\left(0.1-0.3 \mathrm{~d}^{-1}\right)$ throughout the water column. The increase in surface and subsurface growth rates measured between $35^{\circ} \mathrm{S}$ and $45^{\circ} \mathrm{S}$ coincided with a marked increase in the nitrate concentration of the upper mixed layer (Fig. 3C). The region with high growth rates between the Equator and the Mauritanian upwelling $\left(0^{\circ} \mathrm{N}-20^{\circ} \mathrm{N}\right)$ corresponded with the area where $\mathrm{N}_{2}$ fixing cyanobacteria were detectable (Fig. 7D).

\subsection{Biogeochemical provinces}

The concept of biogeochemical provinces stems from the assumption that the ocean can be partitioned into regions with distinct physical, chemical and biological features 


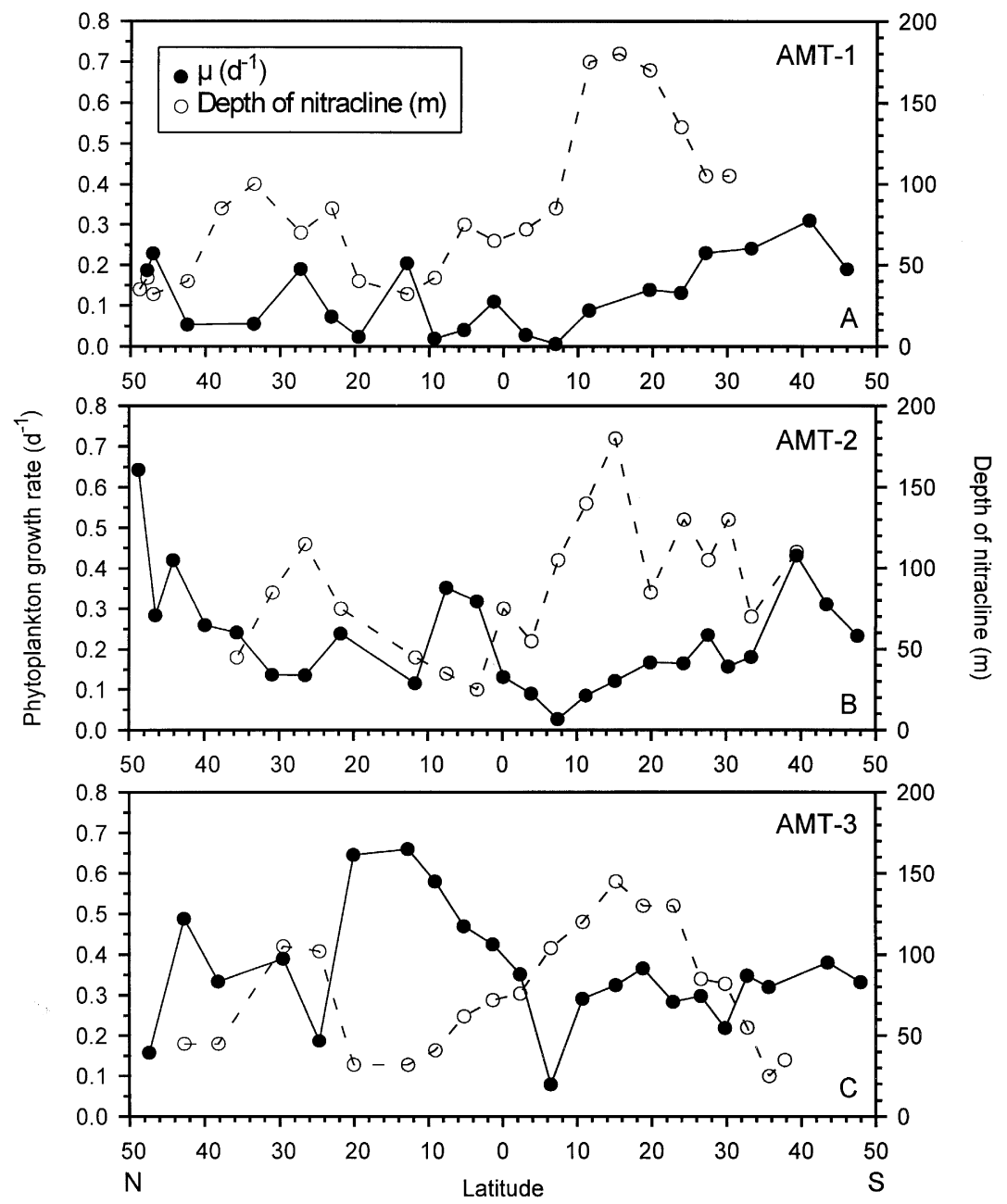

Fig. 11. Latitudinal distribution of surface $(7 \mathrm{~m})$ estimated phytoplankton growth rate $\left(\mathrm{d}^{-1}, 0.69 \times\right.$ doublings per day) and the depth of the nitracline (m) during (A) AMT-1, (B) AMT-2 and (C) AMT-3. See Sections 2 and 3, Methods and Results, for details on calculations.

and has been particularly applied to the estimation of global productivity using satellite imagery (Longhurst et al., 1995). Combining the results from three AMT cruises, we calculated average values of selected biological variables for each biogeochemical region sampled along the transect during each season (Table 1). These calculations summarize the main patterns of latitudinal variation in phytoplankton biomass, production and growth. In addition, they highlight the relative importance of temporal versus spatial variability in the basin-scale distribution of phytoplankton. The five biogeochemical regions considered are [see Longhurst et al. (1995) for a detailed description]: (i) the North Atlantic Drift (NADR, $60^{\circ} \mathrm{N}-40^{\circ} \mathrm{N}$ ), (ii) the North Atlantic 


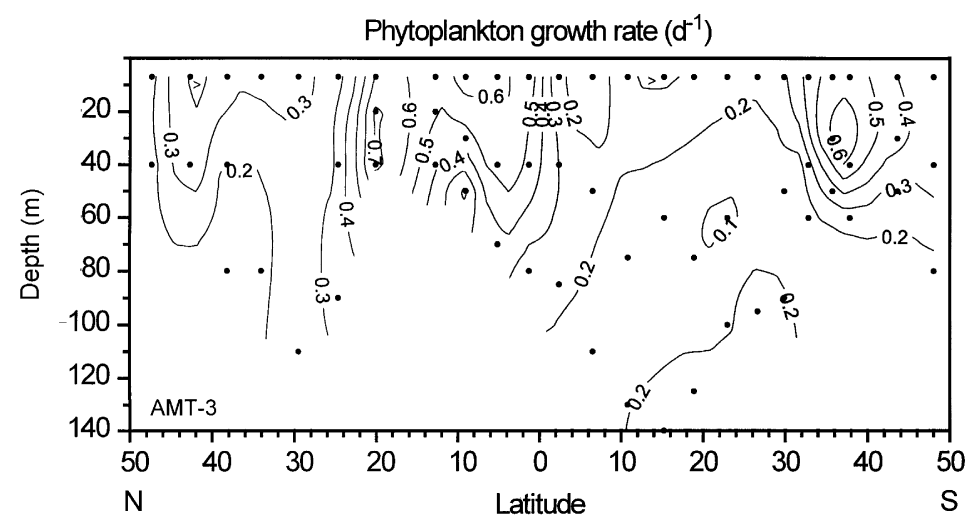

Fig. 12. Latitudinal distribution of estimated phytoplankton growth rate $\left(\mathrm{d}^{-1}, 0.69 \times\right.$ doublings per day) during AMT-3. See Sections 2 and 3, Methods and Results, for details on calculations.

Subtropical Gyre (NAST, $40^{\circ} \mathrm{N}-25^{\circ} \mathrm{N}$ ); (iii) the North Atlantic Tropical Gyre (NATR, $25^{\circ} \mathrm{N}-10^{\circ} \mathrm{N}$ ), (iv) the Western Tropical Atlantic (WTRA, $10^{\circ} \mathrm{N}-5^{\circ} \mathrm{S}$ ) and the South Atlantic Tropical Gyre (SATL, $5^{\circ} \mathrm{S}-40^{\circ}$ S). Table 2 shows the results of the one-way ANOVAs carried out to test the significance of the differences between cruises and regions.

Slightly lower integrated Chl $a$ concentrations were measured during September-October 1996, but the observed differences between cruises were not significant $(p>0.05$, Table 2). Despite the observed latitudinal changes in phytoplankton abundance, differences in integrated $\mathrm{Chl} a$ concentration and surface phytoplankton $\mathrm{C}$ between provinces were not significant due to the high variability within each region. As an exception to this pattern, surface phytoplankton biomass in the NADR was significantly higher $(p<0.01$, Table 2$)$. No significant differences were found between regions in integrated productivity and growth rate, even though major spatial changes were measured on each cruise. By contrast, the increase in production and growth measured during AMT-2 and, especially, AMT-3 was highly significant $(p<0.001$, Table 2). These results would suggest that the regional partition used does not reflect the appropriate scales for the spatial variability of phytoplankton production and growth in the Atlantic Ocean. However, a better seasonal coverage would be required in order to assess if the established limits between regions represent realistic boundaries. In any event, our observations stress the importance of temporal variability, which may override spatial differences.

\section{Discussion}

\subsection{Phytoplankton growth in the oligotrophic regions}

Our measurements of carbon fixation rates and phytoplankton carbon (C) biomass in the oligotrophic regions of the Atlantic Ocean imply growth rates $(\mu)$ that are well 


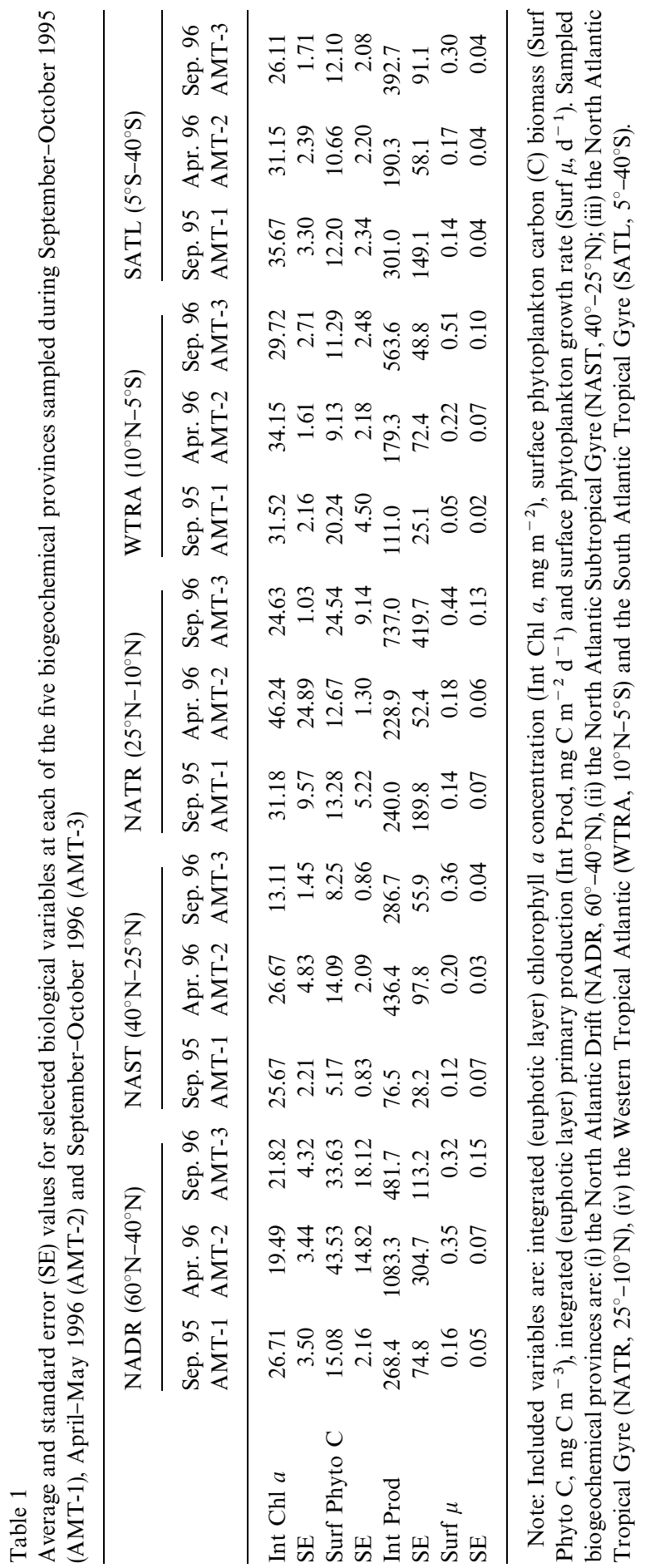


Table 2

Statistical significance of the differences in selected biological variables between cruises and biogeochemical regions (one-way ANOVA)

\begin{tabular}{llllll}
\hline Variable & \multicolumn{2}{l}{ Cruise } & & \multicolumn{2}{l}{ Province } \\
\cline { 2 - 3 } \cline { 5 - 6 } & $p$ & SNK & & $p$ & SNK \\
\hline Int Chl $a$ & $\mathrm{a}$ & $1=2=3$ & & $\mathrm{~ns}$ & $1=2=3=4=5$ \\
Surf Phyto C & $\mathrm{a}$ & $1=2=3$ & & $\mathrm{~b}$ & $1>2=5$ \\
Int Prod & $\mathrm{c}$ & $1=2<3$ & & $\mathrm{~ns}$ & $1=2=3=4=5$ \\
Surf $\mu$ & $\mathrm{d}$ & $1<3$ & & $\mathrm{~ns}$ & $1=2=3=4=5$ \\
\hline
\end{tabular}

Also included are the results from the $a$ posteriori Student-Newmans-Keuls test (SNK, $p \leqslant 0.05$ ) carried out to ascertain the differences between all paired groups. Numbers 1, 2 and 3 denote the three cruises: AMT-1, AMT-2 and AMT-3. For the biogeochemical provinces, NADR, NAST, NATR, WTRA and SATL are respectively referred to by the numbers 1,2, 3, 4 and 5. Abbreviations as in Table 1 .

${ }^{\mathrm{a}} p>0.05$.

${ }^{\mathrm{b}} p<0.05$.

${ }^{\mathrm{c}} p<0.01$.

${ }^{\mathrm{d}} p<0.001$.

below the theoretical maximum $\left(\mu_{\mathrm{m}}\right)$. We calculated the latitudinal distribution of $\mu / \mu_{\mathrm{m}}$ by applying Eppley (1972) empirical relationship between temperature and maximum specific growth rate and assuming a 50\% reduction of growth to correct for the effects of the photoperiod. Estimated surface phytoplankton growth in the oligotrophic regions averaged $15.6 \pm 1.9 \%$ of maximum growth. These results do not support the hypothesis that phytoplankton sustain elevated relative growth rates in nutrient-impoverished areas of the open ocean (Goldman et al., 1979). Similar results have previously been reported by Goericke (1990), Geider et al. (1993) and Malone et al. (1993) using different techniques to estimate the growth rates of phytoplankton in the western Sargasso Sea. Other authors, however, reported high growth rates $\left(>1 \mathrm{~d}^{-1}\right)$ in oligotrophic waters of the North Pacific gyre (Laws et al., 1987) and the equatorial Atlantic Ocean (Herbland and Le Bouteillier, 1983). There is growing evidence that the observed discrepancies between estimates of phytoplankton growth in oligotrophic waters might reflect the natural variability of biological rates rather than methodological deficiencies (Laws et al., 1987; Malone et al., 1993; Letelier et al., 1996). In this regard, Eppley (1981) cautioned against the practice of drawing generalities for large portions of the oceans. However, unlike previous studies, the data presented in this paper span ocean basin scales $(>10,000 \mathrm{~km})$ while including a component of seasonal change over a 14-month period. Despite the observed degree of temporal variability (see below), our results consistently indicate (average surface $\mu=0.21 \pm 0.02 \mathrm{~d}^{-1}$ ) that growth of phytoplankton is slow in the oligotrophic areas of the Atlantic Ocean.

A number of methodological reasons could be invoked to account for the low growth rates estimated in nutrient-poor waters during the present study. Metal-clean techniques were used during collection and incubation of seawater samples throughout this study, and relatively high productivity rates (close to and higher than 
$0.8 \mathrm{~g} \mathrm{C} \mathrm{m}^{-2} \mathrm{~d}^{-1}$ ) were measured at a number of stations in temperate, upwelling and equatorial waters (Fig. 10). Therefore, sample contamination can be ruled out as the reason for the low production measured in the oligotrophic regions. The actual rate of carbon fixation by phytoplankton can also be underestimated if intense recycling of ${ }^{14} \mathrm{C}$ by the microbial food web takes place during the incubation (Peterson, 1980). However, this effect is unlikely to influence the results of short incubations $(6-7 \mathrm{~h})$ such as the ones we used in our study, especially considering the relatively low biomass of microzooplankton $\left(1-3 \mathrm{mg} \mathrm{C} \mathrm{m}^{-3}\right.$, representing $<10 \%$ of total microplankton biomass) and heterotrophic bacteria (2-4 $\mathrm{mg} \mathrm{C} \mathrm{m}^{-3}$, Zubkov et al., 1998) found in the oligotrophic gyres as compared to that of phytoplankton (6-14 $\mathrm{mg} \mathrm{C} \mathrm{m}^{-3}$, Figs. 6A and 7A). In this regard, Gieskes and Kraay (1984) did not find evidence of label transfer to upper trophic levels during incubations lasting up to $12 \mathrm{~h}$. Furthermore, given that we used a conservative correction factor to account for respiratory losses (20\% of light ${ }^{14} \mathrm{C}$ incorporation), our daily carbon fixation rates, if anything, would overestimate rather than underestimate net photosynthesis. This would be particularly true for the central oligotrophic regions, as the ratio between dark respiration and photosynthesis increases under conditions of nutrient limitation (Osborne and Geider, 1986).

In surface waters of the central gyres during AMT-1 and, to a lesser extent, AMT-2, we measured productivities rates below $0.1 \mathrm{mg} \mathrm{C} \mathrm{m}^{-3} \mathrm{~h}^{-1}$ and Chl $a$ concentrations around $0.05 \mathrm{mg} \mathrm{m}^{-3}$, which implied low assimilation numbers of about $1-2 \mathrm{mg} \mathrm{C}$ $\mathrm{mg} \mathrm{Chl} \mathrm{C}^{-1} \mathrm{~h}^{-1}$. Diel variability in photosynthesis could have caused an underestimation of the productivities rates in ${ }^{14} \mathrm{C}$ incubations lasting less than $12 \mathrm{~h}$. Evidence concerning diel oscillations in phytoplankton photosynthesis is contradictory: the peak in C fixation rate may occur in the morning (e.g. Taguchi, 1976; Platt et al., 1980) or in the afternoon (e.g. Harding et al., 1982; Prézelin et al., 1987). Diel variability in photosynthesis appears to be regulated by complex interactions between photoperiod, cell nutritional status and taxonomical composition of the microalgal assemblages, and therefore it is difficult to assess the extent to which it has affected our productivity estimates.

In order to evaluate the effect of the incubation time on the estimated $\mathrm{C}$ uptake rates, short $(7 \mathrm{~h})$ and long $(24 \mathrm{~h})$ incubations were conducted in parallel at 4 stations during the AMT-6 cruise (April 1998), following the same methodology that has been used throughout the AMT programme. A highly significant correlation was found between the results of both types of experiments $\left(r^{2}=0.87, n=16, p<0.001\right)$, and the slope of the linear equation (0.86) was not significantly different from 1 . These observations lead us to conclude that our incubation procedures were not underestimating the productivities in the subtropical gyres. In fact, low productivity to Chl $a$ ratios, similar to the ones we measured during AMT-1 in the North subtropical gyre, have been previously reported for the oligotrophic regions of the Atlantic Ocean. Jochem and Zeitzschel (1993) measured surface assimilations below $0.3 \mathrm{mg} \mathrm{C} \mathrm{mg} \mathrm{Chl}^{-1} \mathrm{~h}^{-1}$ in the eastern subtropical North Atlantic, and Hood (1995), working in the western subtropical South Atlantic, estimated $\mathrm{P}^{\mathrm{B}} \max$ values of $1 \mathrm{mg} \mathrm{C} \mathrm{mg} \mathrm{Chl}{ }^{-1} \mathrm{~h}^{-1}$ at the $50 \%$ light level, thus implying assimilation numbers $<1 \mathrm{mg} \mathrm{C} \mathrm{mg} \mathrm{Chl} l^{-1} \mathrm{~h}^{-1}$. During AMT-3, and also in the subtropical North Atlantic during AMT-2, the 
assimilations we measured were significantly higher ( $>3-4 \mathrm{mg} \mathrm{C} \mathrm{mg} \mathrm{Chl}{ }^{-1} \mathrm{~h}^{-1}$ ). Given that the methodology used during the three cruises was the same, these differences are taken to represent natural variability in the productivity of the central gyres (see below).

Another source of error may arise from the estimation of phytoplankton carbon using microscope cell counts and constant conversion factors. However, there was a very strong correlation between estimated phytoplankton $\mathrm{C}$ (Phyto-C) and chlorophyll $a(\mathrm{Chl} a)$ concentration [Phyto-C $=32.70( \pm 2.41) * \mathrm{Chl} a+6.05( \pm 0.75)$, $r^{2}=0.74, p<0.001, n=66$ for surface samples, see Fig. 8A], even though this ratio shows a large variability depending on the taxonomical composition, nutritional status and growth irradiance of the phytoplankton assemblages (Cullen, 1982). In addition, the mean surface $\mathrm{C}$ to $\mathrm{Chl} a$ ratio $[79.3 \pm 4.2$ for the three cruises] is similar to those reported in the literature for phytoplankton in nutrient-depleted waters of the Atlantic Ocean (Herbland and Le Bouteillier, 1983; Malone et al., 1993). Any significant underestimation or overestimation of the actual microalgal biomass would have resulted in anomalous $\mathrm{C}$ to $\mathrm{Chl} a$ ratios or a poor correlation between surface $\mathrm{Chl} a$ concentration and phytoplankton $\mathrm{C}$ concentration. We observed neither, which supports the use of these phytoplankton C estimates in the calculation of growth rates.

We also found good agreement between the latitudinal variations in cyanobacterial biomass and those of the relative contribution of picoplankton to total integrated $\mathrm{Chl}$ $a$ concentration (Figs. 5B and 6C). Furthermore, the mean cyanobacterial biomass in surface oligotrophic regions during AMT-3 estimated from the cell counts $\left[1.8 \pm 0.3 \mathrm{mg} \mathrm{C} \mathrm{m}^{-3}\right]$ was comparable, within a factor of 2, to that obtained from flow cytometry [3.3 $\left.\pm 0.4 \mathrm{mg} \mathrm{C} \mathrm{m}^{-3}\right]$ (Zubkov et al., 1998). For AMT-3, we recalculated our total phytoplankton $\mathrm{C}$ estimates using flow cytometry-derived picoplankton biomasses and found no significant differences between these new estimates and the ones that were fully based on the microscopy cell counts. These results strongly suggest that our estimates were not severely misrepresenting the actual total biomass of phytoplankton. The comparison between these two sets of data indicates that in the worst scenario our $\mathrm{C}$ estimates would deviate from the real concentrations by a factor of 2 , which would in turn imply an uncertainty level of a factor of 2 for the growth rate estimates. Nonetheless, our conclusion regarding the slow growth of phytoplankton in the oligotrophic region would still hold, given that our estimates of $\mu$ for these regions are lower than the maximum expected values by a factor of 4-5. From this assessment of the methodology used, we conclude that the low estimated growth rates in the oligotrophic regions truly represent substantial deviations from the maximum expected growth rates.

Low turnover rates do not necessarily presuppose limitation of phytoplankton growth if microalgae are intrinsically characterized by low maximum growth rates. It has been suggested that open ocean algae may have adapted to low nutrient conditions by losing their ability to grow fast (Jackson, 1980). However, Brand and Guillard (1981) demonstrated that several species of microalgae isolated from oligotrophic waters have the same growth potential as those cultured in the laboratory, and numerous studies in the central gyres have found growth responses of phytoplankton to experimental nutrient additions (Eppley et al., 1973; DiTullio et al., 1993; Graziano 
et al., 1996; Dufour et al., 1999). During the AMT cruises, we found dramatic increases in productivity and growth in some areas (e.g. the Equator) where the taxonomical composition of the phytoplankton assemblages did not change significantly, which suggests the low $\mu$ values observed in the oligotrophic gyres are indicative of growth limitation rather than reduced growth ability of microalgae. In discussing geographical differences of phytoplankton growth, Banse (1993) suggested that the rates of microalgal division could be controlled by temperature-dependent changes in the rate of nutrient regeneration by zooplankton. If this were the case in the Atlantic Ocean, we would have found increased growth rates in the warm, tropical waters as compared to the temperate waters. The possibility that the latitudinal changes in phytoplankton growth were caused by variations in grazing pressure during the incubations is also unlikely, considering the short duration of the experiments and the relatively low and invariant distribution of microzooplankton abundance throughout the transect.

Irradiance has been shown to be a major factor controlling the temporal variability of the productivity rates during small scale surveys in the subtropical North Atlantic (i.e. Bidigare et al., 1987; Marra et al., 1992). However, recent modelling with large observational datasets has demonstrated that changes in daily integrated irradiance explains only a minor portion $(<15 \%)$ of the variability in integrated primary productivity (Behrenfeld and Falkowski, 1997a,b). In our study, we did not find any evidence supporting irradiance as an important factor in the determination of the large scale, latitudinal distribution of phytoplankton production and growth. Latitudinal variations in $I_{0}$ during April-May 1996 followed an inverse pattern as compared to those observed during September-October 1996, but these differences did not result in comparable, contrasting patterns of productivity or growth. Lowest rates of surface productivity and growth were measured in tropical or subequatorial latitudes (Figs. 9-11), where incident PAR irradiance $\left(I_{0}\right)$ was well above $600 \mu \mathrm{mol} \mathrm{m}{ }^{-2} \mathrm{~s}^{-1}$ (see Fig. 8 in Marañon and Holligan, 1999). It is unlikely that these $I_{0}$ levels were limiting for the growth of surface phytoplankton, considering that the saturation parameter, $I_{k}$, very rarely exceeded $500 \mu \mathrm{mol} \mathrm{m}^{-2} \mathrm{~s}^{-1}$ (Marañón and Holligan, 1999).

When the latitudinal variations in phytoplankton growth rate were examined (Figs. 11 and 12), the following patterns emerged: (i) lowest values were measured in the central oligotrophic gyres; (ii) $\mu$ tended to increase with latitude during spring, and (iii) highest values were found in temperate waters and the upwelling region off NW Africa. The close association observed between phytoplankton production and growth and the depth of the upper mixed layer suggests that nutrient supply could be the limiting factor for phytoplankton growth in the oligotrophic regions of the Atlantic Ocean. In order to estimate the latitudinal changes in the upward diffusion of nutrients from below the thermocline, we used the depth of the nitracline as a proxy for nitrate supply into the upper mixed layer (e.g. Malone et al., 1993). During AMT-2 and AMT-3, a significant inverse relationship existed between surface $\mu$ and the depth of the nitracline (for AMT-2: $r^{2}=0.23, n=17, p<0.05$; for AMT-3: $r^{2}=0.44$, $n=19, p<0.01$; see Fig. 11), and accordingly surface $\mu$ and the integrated concentration of nitrate over the euphotic layer were positively correlated. In some instances, however (particularly during AMT-1), there was a poor correlation between the 
position of the nutricline and the growth rate of phytoplankton. This lack of coupling may reflect the dynamics of the relationship between the physical and chemical fields and the physiological state of phytoplankton, which represents a delayed, integrated response to previous environmental perturbations (Harris, 1986). Nevertheless, despite the great diversity of physical processes operating over large spatial scales (e.g. Olaizola et al., 1996), we still found a significant relationship between phytoplankton growth and the physical and chemical structure of the water column. Similarly, we have shown in a companion study that the light-saturated, chlorophyll $a$-normalized photosynthetic rate was inversely correlated to the depth of the nutricline (Marañón and Holligan, 1999).

Our results emphasize the role of nutrient injection through the thermocline in controlling phytoplankton activity (Platt et al., 1992; Malone et al., 1993; Letelier et al., 1996). Although nitrate was undetectable in surface waters from $30^{\circ} \mathrm{N}$ to $30^{\circ} \mathrm{S}$, nanomolar nitrate increases in upwelling and equatorial waters, resulting from a shallowing of the nutricline, may have given rise to an enhancement of phytoplankton productivity and growth. Nanomolar increases in nitrate concentration have been shown to support high surface productivity in Sargasso Sea waters (Glover et al., 1988), and an inverse correlation between integrated productivity and the depth of the nutricline has been previously reported in several nutrient-poor regions of the Atlantic Ocean (Herbland and Voituriez, 1979; Malone et al., 1993). The notion of the phytoplankton growth rate being nitrogen limited in vast areas of the Atlantic Ocean agrees with the observed geographical distribution of the maximum quantum efficiency of photosynthesis (Geider et al., 1993; Olaizola et al., 1996) and the results of nutrient addition experiments in the North Atlantic (Graziano et al., 1996). Finally, the correlation between the abundance of $\mathrm{N}_{2}$-fixing cyanobacteria and growth rate found between the Equator and $20^{\circ} \mathrm{N}$ during AMT-3 (Figs. 7D and 12) suggests that biological fixation of atmospheric nitrogen can also be an important mechanism in sustaining high biological rates in nutrient-impoverished surface waters (see Karl et al., 1997). These findings stress the necessity for future studies in the oligotrophic Atlantic Ocean of the latitudinal distribution of nanomolar nutrient concentrations and the rate of $\mathrm{N}_{2}$ fixation in relation to phytoplankton productivity and growth.

\subsection{Vertical and latitudinal variability}

The existence of a deep chlorophyll $a$ maximum (DCM) represented the most obvious feature of the vertical distribution of biological variables throughout the transect (Fig. 4). The DCM constitutes a widespread phenomenon in the world oceans and may be formed through a variety of mechanims (Cullen, 1982; Gould, 1987) including accumulation of cells from overlying waters, differential sinking rates, physiological photoacclimation and enhanced in situ growth sustained by nutrient diffusion through the thermocline. During the AMT cruises, we generally found little evidence to support the existence of a phytoplankton biomass maximum at the DCM (see Fig. 7A). In the oligotrophic regions, were the DCM was most developed, the differences in phytoplankton-C biomass between surface $\left(8.95 \pm 0.68 \mathrm{mg} \mathrm{C} \mathrm{m}^{-3}\right)$ and the $\mathrm{DCM}\left(10.43 \pm 0.76 \mathrm{mg} \mathrm{C} \mathrm{m}^{-3}\right)$ were not significant (paired $t$-rest, $p>0.1, n=25$ ). 
In contrast, the average $\mathrm{C}$ to $\mathrm{Chl} a$ ratio at the DCM was $39.6 \pm 5.2$, compared with $86.6 \pm 6.5$ at the surface. These observations agree with those of Goericke (1990) and Claustre and Marty (1995) in the tropical North Atlantic and indicate that in oligotrophic waters the DCM is mainly the result of a decrease in the $\mathrm{C}$ to $\mathrm{Chl} a$ ratio, reflecting the photoacclimation of cells to low irradiance and possibly higher nutrient availability (Cullen, 1982). The low photosynthesis to Chl $a$ ratios $(<1 \mathrm{mgC}$ $\left.\mathrm{mg} \mathrm{Chl}{ }^{-1} \mathrm{~h}^{-1}\right)$ and growth rates $\left(<0.2 \mathrm{~d}^{-1}\right)$ are consistent with previous studies in the North Atlantic (Platt et al., 1983; Fasham et al., 1985; Malone et al., 1993) and suggest a slow turnover for the phytoplankton populations inhabiting the DCM. Accordingly, we did not find any significant correlation between the depth of the DCM and the depth of the production maximum. Furthermore, the surface Chl $a$ concentration was a better predictor of integrated productivity than the integrated Chl $a$ concentration.

The uncoupling between the vertical distribution of Chl $a$ and that of production contrasts with the results of Herbland and Voituriez (1979), who found the depths of the DCM and the productivity maximum to be statistically the same in the eastern tropical Atlantic Ocean. A possible explanation for this discrepancy may be related to the effects of the equatorial upwelling in terms of increased vertical mixing, shoaling of the nutricline and nutrient enrichment of the upper mixed layer. These effects are particularly intense in the eastern tropical Atlantic (Vinogradov, 1981; Oudot and Morin, 1987), where most of the observations by Herbland and Voituriez (1979) were conducted. If the upward diffusion of nutrients increases and the depth of the thermocline becomes shallower, phytoplankton at the DCM would respond with higher photosynthetic rates and an enhanced contribution to the total integrated productivity. Our observations in equatorial waters support this interpretation, as the magnitude of the DCM tended to be higher there (Fig. 4), giving way in some cases to deep productivity maxima (Fig. 9). By contrast, when the nitrate-depleted layer is deep $(>80-100 \mathrm{~m})$ light limitation at the DCM prevents the existence of a productivity maximum. In conclusion, our results in subtropical and tropical areas not affected by the equatorial upwelling support the case for a relatively minor contribution of the DCM to total integrated biomass and productivity.

The changes along the transect in Chl $a$ concentration and primary production reflected the interaction between the physical field and the biological responses of the planktonic ecosystem (Figs. 4 and 9). Accumulation of phytoplankton biomass and enhanced levels of productivity took place at those areas where increased vertical mixing allowed for the existence of higher levels of nutrients in subsurface, well illuminated layers (temperate waters during spring bloom conditions) or the depth of the nutricline shoaled, presumably favouring the injection of nutrients into a shallower mixed layer (upwelling and equatorial waters). These latitudinal patterns were also reflected in the distribution of relative growth rates $\left(\mu / \mu_{\mathrm{m}}\right)$ : highest values of $\mu / \mu_{\mathrm{m}}$ (0.6-1.0) were always measured at temperate latitudes during spring, indicating relatively fast growth of phytoplankton. Although surface Chl $a$ concentration and integrated primary production covaried throughout the transect, the regression analysis showed that changes in surface $\mathrm{Chl} a$ explained less than $50 \%$ of the latitudinal variability in water column productivity. We interpret these results as suggesting that 
spatial differences in euphotic layer productivity are strongly dependent on the biomass specific rates of production (e.g. Malone et al., 1993) and not only on the levels of photosynthetic biomass. A similar mechanism is suggested below to account for the observed variability between cruises.

\subsection{Temporal variability}

We found an unexpected degreee of temporal variability when comparing the productivity and growth rates of phytoplankton in oligotrophic regions during different cruises (Figs. 9-11). Productivity and growth in tropical waters varied in excess of 8-fold, from $\sim 50$ to $\sim 400 \mathrm{mg} \mathrm{C} \mathrm{m}^{-2} \mathrm{~d}^{-1}$ and $\sim 0.05$ to $\sim 0.4 \mathrm{~d}^{-1}$, respectively. Given that the same experimental procedures were used throughout this study, these changes are considered to reflect the natural variability in the dynamics of the phytoplankton assemblages. This interpretation is additionally supported by the results of the photosynthesis-irradiance (P-E) experiments, which were carried out independently in laboratory incubators (Marañón and Holligan, 1999). The interseasonal changes in the P-E parameters coincided with those observed in the productivity and growth rates. Our findings confirm recent results showing high temporal variability in open ocean, nutrient depleted waters (Malone et al., 1993; Letelier et al., 1996) and invalidate the traditional view of oligotrophic ocean regions as systems whose biological properties are constant over time. However, the available data do not allow us to determine which factors are responsible for the observed variability in the biological rates in the central gyres.

The increase in the productivity of the North Atlantic during April-May 1996 (AMT-2) as compared to September-October 1995 (AMT-1) can be related to seasonal changes in the structure of the water column (Fig. 2) affecting the depth of the nutrient-depleted upper mixed layer (Fig. 3). During AMT-2, nutrient depleted waters extended latitudinally over a smaller area, and accordingly the depth of the nutricline was shallower on average (Fig. 3). Similarly, the increase in water column productivity in the South Atlantic during September-October 1996 (AMT-3) as compared to the previous two cruises could be associated with the existence of detectable levels of nutrients in the upper mixed layer (Fig. 3). This elevation of nutrient concentrations may be caused by several non-exclusive mechanisms, including increased diffusion from below the thermocline (e.g. Klein and Coste, 1984) and atmospheric inputs (e.g. Paerl et al., 1990). Additional studies involving the determination of nanomolar nutrient concentrations are clearly required to confirm the temporal association between nutrient supply and phytoplankton growth. It is important to stress that, in contrast with previous studies reporting temporal differences in productivity associated with variations in nutrient supply (e.g. Glover et al., 1988; Olson et al., 1990; Marra et al., 1992), the changes we observed in the rate of primary production were not accompanied by a similar degree of variability in phytoplankton biomass, which remained remarkably constant in oligotrophic waters throughout the three cruises (Fig. 6). The relative constancy of phytoplankton biomass in spite of the changes in productivity supports an important role for grazing as a proximate control of microalgal stocks. 
Our observations are relevant to the estimation of global ocean productivity and the use of the biogeochemical province approach in conjunction with remote sensing measurements of phytoplankton pigments (e.g. Longhurst et al., 1995). In their analysis of the variability of the phytoplankton community in the North Pacific, Winn et al. (1995) stressed the importance of photoadaptation in determining the seasonal changes in Chl $a$ concentration. These authors suggested that satellite-based estimates of pigment abundance should not be used to describe the temporal variations in algal biomass without correcting for the changes in the cellular $\mathrm{Chl} a$ to $\mathrm{C}$ ratio. In a similar way, our results imply a significant degree of uncoupling between the changes in productivity and those of Chl $a$ concentration, as the Chl $a$-specific rate of photosynthesis varied over more than 1 order of magnitude both geographically and temporally. This degree of variability in the biomass specific rate of primary production is at least three times larger than currently assumed in satellite-based models of oceanic productivity (e.g. Sathyendranath et al., 1995) and illustrates the limitations of the biogeochemical province approach, as Behrenfeld and Falkowski (1997a) have pointed out. Increased efforts should therefore be devoted to the development of geographically continuous functions that are based on sea-truth measurements and relate relevant environmental variables to the biomass specific rate of phytoplankton production on a global scale.

\section{Acknowledgements}

We wish to thank principal scientist David B. Robins (PML) for his help during work at sea, as well as the captain and crew of the RRS James Clark Ross (British Antarctic Survey) for excellent support and smooth sailing. The assistance of Nigel Rees (Plymouth Marine Laboratory) was instrumental in accessing the AMT database. Alan Pomroy, Colin Griffiths and Malcolm Woodward (PML) provided nutrient data. Phytoplankton species data were supplied by Derek Harbour (PML). Thanks are also given to Mike Zubkov for allowing our access to his picoplankton data from AMT-3. Comments by Mike Fasham, Toby Tyrrell, John Marra and two anonymous referees improved an earlier version of the manuscript. E.M. acknowledges the receipt of a Marie Curie research training grant from the European Union. This work was supported by research grants from the UK National Environmental Research Council (NERC) and the US National Aeronautics and Space Administration (NASA). This is AMT contribution No 31.

\section{References}

Agustí, S., Duarte, C.M., 1999. Phytoplankton chlorophyll a distribution and water column stability in the Atlantic Ocean. Oceanologica Acta 22, 193-203.

Banse, K., 1993. On the dark bottle in the ${ }^{14} \mathrm{C}$ method for measuring marine phytoplankton production. In:

Li, W., Maestrini, S.Y. (Eds.), Measurement of Primary Production from the Molecular to the Global Scale. ICES Marine Science Symposia, 197, pp. 132-140. 
Banse, K., 1995. Zooplankton: pivotal role in the control of ocean production. ICES Journal of Marine Science 52, 265-277.

Behrenfeld, M.J., Falkowski, P.G., 1997a. Photosynthetic rates derived from satellite-based chlorophyll concentration. Limnology and Oceanography 42, 1-20.

Behrenfeld, M.J., Falkowski, P.G., 1997b. A consumer's guide to phytoplankton productivity models. Limnology and Oceanography 42, 1479-1491.

Bidigare, R.R., Smith, R.C., Baker, K.S., Marra, J., 1987. Oceanic primary production estimates from measurements of spectral irradiance and pigment concentrations. Global Biogeochemical Cycles 1, 171-186.

Brand, L.E., Guillard, R.R.L., 1981. The effects of continuous light and light-intensity on the reproduction rates of 22 species of marine phytoplankton. Journal of Experimental Marine Biology and Ecology 50, $119-132$.

Capone, D.G., Zehr, J.P., Paerl, H.W., Bergman, B., Carpenter, E.J., 1997. Trichodesmium, a globally significant marine cyanobacterium. Science 276, 1221-1229.

Claustre, H., Marty, J.C., 1995. Specific phytoplankton biomasses and their relation to primary production in the tropical North Atlantic. Deep-Sea Research 42, 1475-1493.

Codispoti, L.A., Friederich, G.E., 1978. Local and mesoscale influences on nutrient variability in the northwest African upwelling region near Cabo Corbeiro. Deep-Sea Research 25, 751-770.

Cox, J.L., Wiebe, P.H., Ortner, P., Boyd, S., 1982. Seasonal development of subsurface chlorophyll maxima in slope water and northern Sargasso Sea of the northwestern Atlantic Ocean. Biological Oceanography $1,271-285$.

Cullen, J.J., 1982. The deep chlorophyll maximum: comparing vertical profiles of chlorophyll a. Canadian Journal of Fisheries and Aquatic Sciences 39, 791-803.

DiTullio, G.R., Hutchins, D.A., Bruland, K.W., 1993. Interaction of iron and major nutrients controls phytoplankton growth and species composition in the tropical North Pacific Ocean. Limnology and Oceanography 38, 495-508.

Dufour, P., Charpy, L., Bonnet, S., Garcia, N., 1999. Phytoplankton nutrient control in the oligotrophic South Pacific subtropical gyre (Tuamotu Archipelago). Marine Ecology Progress Series 179, 285-290.

Eppley, R.W., 1972. Temperature and phytoplankton growth in the sea. Fishery Bulletin 70, $1063-1085$

Eppley, R. W., 1981. Relationship between nutrient assimilation and growth rate in phytoplankton with a brief review of estimates of growth rate in the ocean. In: Platt, T. (Ed.), Physiological Bases of Phytoplankton Ecology, Canadian Bulletin of Fisheries and Aquatic Sciences, Vol. 210, pp. 251-263.

Eppley, R.W., Renger, E.H., Venrick, E.L., Mullin, M.M., 1973. A study of plankton dynamics and nutrient cycling in the central gyre of the North Pacific Ocean. Limnology and Oceanography 18, 534-551.

Falkowski, P.G., Greene, R.M., Geider, R.J., 1992. Physiological limitations on phytoplankton productivity in the ocean. Oceanography 5, 84-91.

Fasham, M.J.R., Platt, T., Irwin, B., Jones, K., 1985. Factors affecting the spatial pattern of the deep chlorophyll maximum in the region of the Azores front. Progress in Oceanography 14, 129-165.

Fitzwater, S.E., Knauer, G.A., Martin, J.H., 1982. Metal contamination and its effect on primary production measurements. Limnology and Oceanography 27, 544-551.

Frazel, D.W., Berberian, G., 1990. Distribution of chlorophyll and primary productivity in relation to water column structure in the eastern North Atlantic Ocean. Global Biogeochemical Cycles 4, 241-251.

Fuhrman, J.A., Sleeter, T.D., Carlson, C.A., Proctor, L.M., 1989. Dominance of bacterial biomass in the Sargasso Sea and its ecological implications. Marine Ecology Progress Series 57, 207-217.

Geider, R. J., 1992. Respiration: taxation without representation? In: Falkowski, P.G., Woodhead, A.D., Primary Productivity and Biogeochemical Cycles in the Sea. Plenum Press, New York,pp. 333-360.

Geider, R.J., Greene, R.M., Kolber, Z., MacIntyre, H.L., Falkowski, P.G., 1993. Fluorescence assessment of the maximum quantum efficiency of photosynthesis in the western North Atlantic. Deep-Sea Research I 40, 1205-1224. 
Gieskes, W.W., Kraay, G.W., 1984. State-of-the-art in the measurement of primary production. In: Fasham, M.R. (Ed.), Flow of Energy and Materials in Marine Ecosystems, NATO Advanced Research Institute. Plenum Press, New York, pp. 171-190.

Glover, H.E., Prezelin, B.B., Campbell, L., Wyman, M., Garside, C., 1988. A nitrate-dependent Synechococcus bloom in surface Sargasso Sea water. Nature 331, 161-163.

Goericke, R., 1990. Pigments as ecological tracers for the study of the abundance and growth of marine phytoplankton. Ph.D. Thesis, Harvard University, 418 pp.

Goldman, J.C., McCarthy, J.J., Peavey, D.G., 1979. Growth rate influence on the chemical composition of phytoplankton in oceanic waters. Nature 279, 210-215.

Gould, R.W., 1987. The deep chlorophyll maximum in the world ocean: a review. The Biologist 66, 4-13.

Graziano, L.M., Geider, R.J., Li, W.K.W., Olaizola, M., 1996. Nitrogen limitation of North Atlantic phytoplankton: analysis of physiological condition in nutrient enrichment experiments. Aquatic Microbial Ecology 11, 53-64.

Harding, L.W., Prézelin, B.B., Sweeney, B.M., Cox, J.L., 1982. Diel oscillations of the photosynthesis-irradiance (P-I) relationship in natural assemblages of phytoplankton. Marine Biology 67, $167-178$.

Harris, G.P., 1986. Phytoplankton Ecology: Structure, Function and Fluctuation. Chapman and Hall, London.

Herbland, A., Le Bouteiller, A., 1981. The size distribution of phytoplankton and particulate organic matter in the Equatorial Atlantic Ocean: importance of ultraseston and consequences. Journal of Plankton Research 3, 659-673.

Herbland, A., Le Bouteiller, A., 1983. Dynamique du phytoplankton et matière organique particulaire dans la zone euphotique de l'Atlantic Equatorial. Marine Biology 72, 265-278.

Herbland, A., Voituriez, B., 1979. Hydrological structure analysis for estimating the primary production in the tropical Atlantic Ocean. Journal of Marine Research 37, 87-101.

Holligan, P.M., Harris, R.P., Newell, R.C., Harbour, D.S., Linley, E.A.S., Lucas, M.I., Tranter, P.R.G., Weekley, C.M., 1984. Vertical distribution and partitioning of organic carbon in mixed, frontal and stratified waters of the English Channel. Marine Ecology Progress Series 14, 111-127.

Hood, R.R., 1995. Light response of phytoplankton in the South Atlantic Ocean: interpretation of observations and application to remote sensing. Journal of Geophysical Research 100 (C6), $10927-10942$.

Iturriaga, R., Marra, J., 1988. Temporal and spatial variability of chroococcoid cyanobacteria Synechococcus spp. specific growth rates and their contribution to primary production in the Sargasso Sea. Marine Ecology Progress Series 44, 175-181.

Jackson, G.A., 1980. Phytoplankton growth and zooplankton grazing in oligotrophic waters. Nature 284, 439-441.

Jochem, F.J., Zeitz-schel, B., 1993. Productivity regime and phytoplankton size structure in the tropical and subtropical North Atlantic in spring 1989. Deep Sea Research II 40, 495-519.

Karl, D.M., Christian, J.R., Dore, J.E., Hebel, D.V., Letelier, R.M., Tupas, L.M., Winn, C.W., 1996. Seasonal and interannual variability in primary production and particulate flux at Station ALOHA. Deep-Sea Research II 43, 539-568.

Karl, D.M., Letelier, R.M., Tupas, L.M., Christian, J.R., Hebel, D.V., 1997. The role of nitrogen fixation in biogeochemical cycling in the subtropical North Pacific Ocean. Nature 388, 533-538.

Karl, D.M., Lukas, R., 1996. The Hawaii Ocean Time-series (HOT) program: background, rationale and implementation. Deep-Sea Research II 43, 129-156.

Klein, P., Coste, B., 1984. Effects of wind-stress variability on nutrient transport into the mixed layer. Deep-Sea Research 31, 21-37.

Laws, E.A., DiTullio, G.R., Redalje, D.G., 1987. High phytoplankton growth and production rates in the North Pacific subtropical gyre. Limnology and Oceanography 32, 905-918.

Le Bouteiller, A., Blanchot, J., Rodier, M., 1992. Size distribution patterns of phytoplankton in the western Pacific: towards a generalization for the tropical open ocean. Deep-Sea Research 39, 805-823.

Letelier, R.M., Dore, J.E., Winn, C.D., Karl, D.M., 1996. Seasonal and interannual variations in photosynthetic carbon assimilation at Station ALOHA. Deep-Sea Research II 43, 467-490. 
Lohrenz, S.E., Knauer, G.A., Asper, V.L., Tuel, M., Michaels, A.F., Knap, A.H., 1992. Seasonal variability in primary production and particle flux in the Northwestern Sargasso Sea: U.S. JGOFS Bermuda time-series study. Deep-Sea Research 39, 1373-1391.

Longhurst, A., Sathyendranath, S., Platt, T., Caverhill, C., 1995. An estimate of global primary production in the ocean from satellite radiometer data. Journal of Plankton Research 17, 1245-1271.

Malone, T.C., Pike, S.E., Conley, D.J., 1993. Transient variations in phytoplankton productivity at the JGOFS Bermuda time series station. Deep-Sea Research I 40, 903-924.

Marañón, E., Holligan, P.M., 1999. Photosynthetic parameters of phytoplankton from $50^{\circ} \mathrm{N}$ to $50^{\circ} \mathrm{S}$ in the Atlantic Ocean. Marine Ecology Progress Series 176, 191-203.

Marra, J., Dickey, T., Chamberlin, W.S., Ho, C., Granata, T., Kiefer, D.A., Langdon, C., Smith, R., Baker, K., Bidigare, R., Hamilton, M., 1992. Estimation of seasonal primary production from moored optical sensors in the Sargasso Sea. Journal of Geophysical Research 97 (C5), 7399-7412.

McCarthy, J.J., Goldman, J.C., 1979. Nitrogenous nutrition of marine phytoplankton in nutrient-depleted waters. Science 203, 670-672.

Olaizola, M., Geider, R.J., Harrison, W.G., Graziano, L.M., Ferrari, G.M., Schlittenhardt, P.M., 1996. Synoptic study of variations in the fluorescence-based maximum quantum efficiency of photosynthesis across the North Atlantic Ocean. Limnology and Oceanography 41, 755-765.

Olson, R.J., Chisholm, S.W., Zettler, E.R., Altabet, M.A., Dusenberry, A., 1990. Spatial and temporal distribution of prochlorophyte picoplankton in the North Atlantic Ocean. Deep-Sea Research 37, 1033-1051.

Osborne, B.A., Geider, R.J., 1986. Effect of nitrate-nitrogen limitation on photosynthesis of the diatom Phaeodactylum tricornutum Bohlin (Bacillariophyceae). Plant Cell and Environment 9, 617-625.

Oudot, C., Morin, P., 1987. The distribution of nutrients in the equatorial Atlantic: relation to physical processes and phytoplankton biomass. Oceanologica Acta, Proceedings International Symposium on Equatorial Vertical Motion, pp. 121-130.

Paerl, H.W., Rudek, J., Mallin, M.A., 1990. Stimulation of phytoplankton production in coastal waters by natural rainfall input: nutritional and trophic implications. Marine Biology 107, 247-254.

Peterson, B.J., 1980. Aquatic primary productivity and the ${ }^{14} \mathrm{C}-\mathrm{CO}_{2}$ method: a history of the productivity problem. Annual Review of Ecology and Systematics 11, 359.

Platt, T., Gallegos, C.L., Harrison, W.G., 1980. Photoinhibition of photosynthesis in natural assemblages of marine phytoplankton. Journal of Marine Research 38, 687-701.

Platt, T., Harrison, W.G., 1985. Biogenic fluxes of carbon and oxygen in the ocean. Nature 318, 55-58.

Platt, T., Harrison, W.G., Lewis, M.R., Li, W.K.W., Sathyendranath, S., Smith, R.E., Vezina, A.F., 1989. Biological production of the ocean: the case for a consensus. Marine Ecology Progress Series 52, 77-88.

Platt, T., Sathyendranath, S., Ulloa, O., Harrison, W.G., Hoepffner, N., Goes, J., 1992. Nutrient control of phytoplankton photosynthesis in the Western North Atlantic. Nature 356, 229-231.

Platt, T., Subba Rao, D.V., Irwin, B., 1983. Photosynthesis of picoplankton in the oligotrophic ocean. Nature 301, 702-704.

Prézelin, B.B., Bidigare, R.R., Matlick, H.A., Putt, M., Ver Hoven, B., 1987. Diurnal patterns of sizefractionated primary productivity across a costal front. Marine Biology 96, 563-574.

Sathyendranath, S., Longhurst, A., Caverhill, C.M., Platt, T., 1995. Regionally and seasonally differentiated primary production in the North Atlantic. Deep-Sea Research 42, 1773-1802.

Steeman-Nielsen, E., Jensen, E.A., 1957. Primary oceanic production, the autotrophic production of organic matter in the oceans. Galathea Report 1, 49-136.

Taguchi, S., 1976. Short-term variability of photosynthesis in natural marine phytoplankton populations. Marine Biology 37, 197-207.

Thomas, W.H., 1970. On nitrogen deficiency in tropical Pacific Ocean phytoplankton: photosynthetic parameters in rich and poor waters. Limnology and Oceanography 15, 380-385.

Vinogradov, M.E., 1981. Ecosystems of equatorial upwellings. In: Longhurst, A.R. (Ed.), Analysis of Marine Ecosystems. Academic Press, London, pp. 69-93.

Waterbury, J.B., Watson, S.W., Guillard, R.R., Brand, L.E., 1979. Widespread occurrence of a unicellular marine plankton cyanobacteria. Nature 277, 301-314. 
Winn, C.D., Campbell, L., Christian, J.R., Letelier, R.M., Hebel, D.V., Dore, J.E., Fujieki, L., Karl, D.M., 1995. Seasonal variability in the phytoplankton community of the North Pacific subtropical gyre. Global Biogeochemical Cycles 9, 605-620.

Zubkov, M.V., Sleigh, M.A., Tarran, G.A., Burkill, P.H., Leakey, R.J.G., 1998. Picoplanktonic community structure on an Atlantic transect from $50^{\circ} \mathrm{N}$ to $50^{\circ} \mathrm{S}$. Deep-Sea Research 45, 1339-1355. 